Nordisk Pendlingskarta

Delrapport 1 - Sverige och Norge 



\section{Nordisk Pendlingskarta}

\section{Delrapport 1 - Sverige och Norge}

\section{TemaNord 2004:514}




\section{Nordisk Pendlingskarta \\ Delrapport 1 - Sverige och Norge}

TemaNord 2004:514

(C) Nordisk Ministerråd, København 2004

ISBN 92-893-0997-0

ISSN 0908-6692

Sælges gennem Nordisk Ministerråds salgsagenter, se listen på sidste side.

Nordisk Ministerråd

Store Strandstræde 18

DK-1255 København K

Telefon $(+45) 33960200$

Telefax (+45) 33960202

\section{Nordisk Råd}

Store Strandstræde 18

DK-1255 København K

Telefon $(+45) 33960400$

Telefax $(+45) 33111870$

wWw.norden.org

\section{Regionalpolitisk samarbete i Norden}

Det nordiska regionalpolitiska samarbetet syftar att genom både myndighetssamarbetet på centralt nivå och lokalt och regional initierat samarbete mellan regionerna främja en balanserad regional utveckling i Norden såväl inom de olika länderna som över nationsgränserna.

\section{Nordisk Ministerråd}

blev oprettet i 1971 som samarbejdsorgan mellem de nordiske landes regeringer. Ministerrådet fremlægger forslag til Nordisk Råds sessioner, viderefører rådets rekommandationer, rapporterer til Nordisk Råd om samarbejdets resultater og leder arbejdet inden for de forskellige emneområder. Samarbejdet koordineres af samarbejdsministrene, der er udpeget af det enkelte lands regering. Ministerrådet træder sammen i forskellige sammensætninger - afhængigt af hvilke spørgsmål, der skal behandles.

\section{Nordisk Råd}

blev oprettet i 1952 som et samarbejdsorgan mellem de folkevalgte forsamlinger og regeringer i Danmark, Island, Norge og Sverige. Finland indtrådte i 1955. Færøernes, Grønlands og Ålands delegationer indgår i henholdsvis Danmarks Riges og Finlands delegationer. Rådet består af 87 medlemmer. Nordisk Råd er initiativtagende og rådgivende og har kontrollerende opgaver i det nordiske samarbejde. Nordisk Råds organer er plenarforsamlingen, præsidiet og udvalgene. 


\section{Innhold}

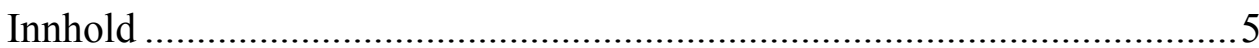

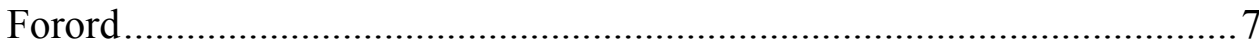

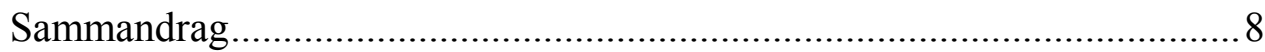

1. Arbetskraftsrörlighet mellan Sverige och Norge …........................... 11

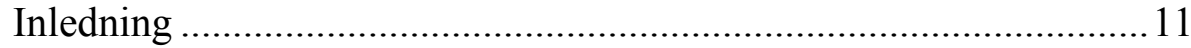

1.2 Populationsavgränsning ............................................................. 11

1.3 Befolkningsfördelning i gränsområdet mellan Sverige och Norge12

2. Statistikbyråernas förutsättningar .................................................. 13

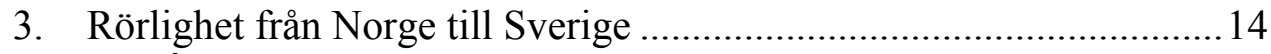

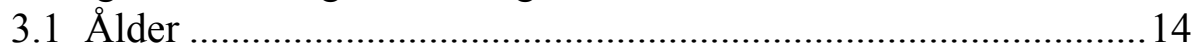

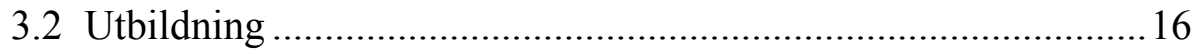

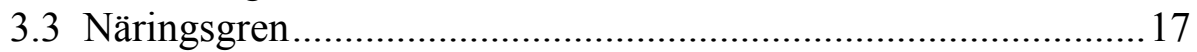

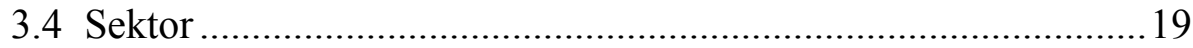

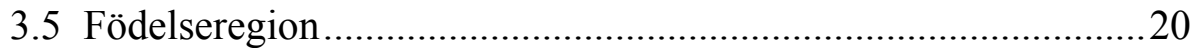

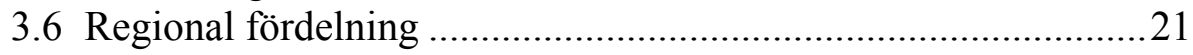

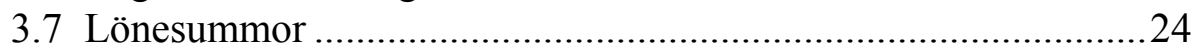

4. Rörlighet från Sverige till Norge ......................................................2 27

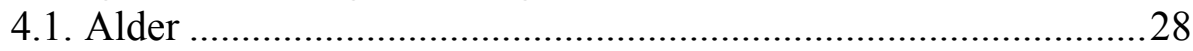

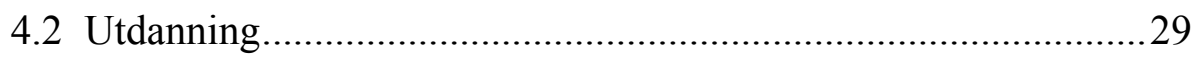

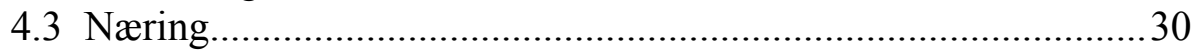

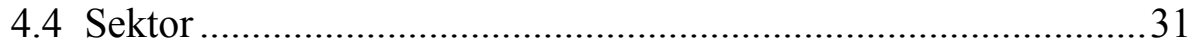

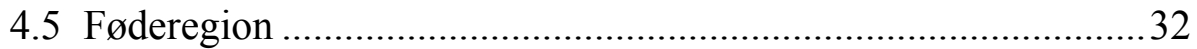

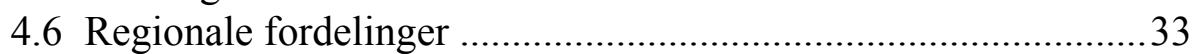

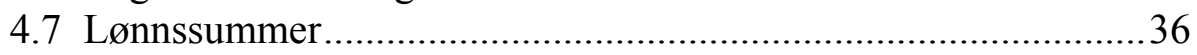

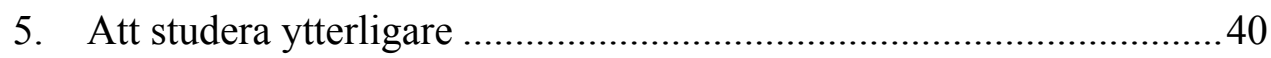

Bilaga 1. Metodbeskrivning ................................................................ 41 


\section{Forord}

Sedan mer än femtio år har det funnits ambitioner inom det nordiska samarbetet att utveckla förutsättningar för en väl fungerande nordisk arbetsmarknad. En del i detta arbete har varit att förbättra kunskapen om hur rörlighet och samverkan ser ut på den nordiska arbetsmarknaden. De statistiska redovisningar med nordiskt perspektiv som hittills presenterats har i huvudsak byggt på sammanställningar av befintliga nationella data. Med projektet "Nordisk pendlingskarta" har fyra nordiska statistikmyndigheter fått möjlighet att sambearbeta data. Syftet med samarbetet har varit att beskriva den gränsöverskridande arbetsmarknaden under 2001. Utbyte av material mellan myndigheterna har föregåtts av en särskild prövning i varje land.

Resultaten redovisas på nationell, regional och kommunal nivå. Därmed beskrivs även rörligheten inom de nordiska gränsregionerna. Tidigare har gränsöverskridande statistik om arbetspendling endast redovisats för Öresundsregionen. Detta är första gången en samlad redovisning nu presenteras.

Projektet Nordisk pendlingskarta 2001 genomförs i samverkan mellan Danmarks Statistik, Statistiska Centralbyrån i Sverige, Statistisk sentralbyrå i Norge och Statistikcentralen i Finland. Projektet omfattar fem delavsnitt avseende pendling mellan Norge och Sverige, Danmark och Norge, Danmark och Sverige, Sverige och Finland samt Norge och Finland. Resultaten kommer att sammanfattas i en slutrapport.

Arbetet med metoder, beräkningar och redovisningar i denna rapport av pendling mellan Sverige och Norge har utförts av Björn Mathisen och Ahmed Muhammed vid Statistisk sentralbyrå samt Carl-Gunnar Hanaeus, Maria Håkansson och Gunnar Hedin vid Statistiska Centralbyrån. Berndt Hermansson vid Statistiska centralbyrån i Örebro har varit koordinator för projektet.

För finansiering av projektet samt för tryck och distribution av rapporten svarar Nordiska Ministerrådet. 


\section{Sammandrag}

Att beskriva nationella arbetsmarknaders samverkan över en riksgräns kan göras utifrån olika utgångspunkter till exempel genom:

- $\quad$ antalet arbetspendlare över riksgräns

- antalet löntagare

- lönesumma för löntagare eller arbetspendlare över riksgräns

- studerande över riksgräns

- flyttare

I denna rapport redovisas rörligheten mellan norsk och svensk arbetsmarknad i form av pendling över riksgräns mellan de båda länderna. Pendlingen redovisas här dels som antalet personer som har huvudsaklig inkomst i det land de pendlar till - arbetspendlare över riksgräns - vilket är det vedertagna pendlingsbegreppet, dels som antalet personer som över huvud taget haft någon form av löneutbetalning i det andra landet. Vi har även beräknat lönesummor för de olika grupperna

Lönesumman som begrepp står för det summerade beloppet av flera "bruttolöner" eller utbetalda löner enligt arbetsgivarnas kontrolluppgifter exempelvis för grupper av människor som bor i en kommun eller efter annan geografisk indelning. Lönesummeredovisningen är till för att ge en bild av den ekonomiska betydelsen av den gränsöverskridande verksamheten i stort. I samlade tabeller har vi räknat om norska kronor till svenska. I avsnitten 3 och 4 är det respektive lands valutanivå som gäller.

Svenska och norska skatte- och lönesystem inte är lika. Prisnivåerna ligger högre i Norge. Därför går det inte att dra några slutsatser av skillnader i lönesummor mellan Sverige och Norge för den enskilde personens konsumtionsmöjligheter eller levnadsstandard, vilket inte heller är meningen med vår redovisning.

32500 svenskar och norrmän hade ett arbete med löneinkomst i grannlandet under 2001. 87 procent av dessa var svenskar som hade löneinkomster i Norge och 13 procent var norrmän som hade löneinkomster i Sverige.

Den totala lönesumman 2001 för boende i Sverige som hade löneutbetalningar i Norge var nästan 3,5 miljarder SEK medan boende i Norge tjänade 0,34 miljarder SEK i Sverige. Lönesumman för boende i Sverige var således 10 gånger större än den var för boende i Norge med löneinkomst i Sverige 
Tabell 1. Personer folkbokförda i Sverige med inkomster i Norge, respektive folkbokförda i Norge med inkomster i Sverige, år 2001. Inkomsterna är omräknade till svensk valuta

\begin{tabular}{|c|c|c|c|c|c|c|c|c|c|c|}
\hline \multirow[t]{3}{*}{$\begin{array}{l}\text { Folkbok- } \\
\text { förings- } \\
\text { land }\end{array}$} & \multirow[t]{3}{*}{$\begin{array}{l}\text { Totalt antal } \\
\text { med in- } \\
\text { komst i det } \\
\text { andra landet } \\
\end{array}$} & & & & & \multirow[t]{3}{*}{$\begin{array}{l}\text { därav antal } \\
\text { arbetspendlare }{ }^{1)} \\
\text { över riksgräns }\end{array}$} & & & & \\
\hline & & deras & & & & & \multicolumn{4}{|l|}{ deras } \\
\hline & & $\begin{array}{l}\text { löne- } \\
\text { summa } \\
\text { i Sverige, } \\
\text { mkr }\end{array}$ & $\begin{array}{l}\text { genom- } \\
\text { snittlida } \\
\text { löneinkomst } \\
\text { i Sverige }\end{array}$ & $\begin{array}{l}\text { löne- } \\
\text { summa } \\
\text { i Norge, } \\
\text { mkr }\end{array}$ & $\begin{array}{l}\text { genom- } \\
\text { snittliga } \\
\text { löneinkomst } \\
\text { i Norge }\end{array}$ & & $\begin{array}{l}\text { löne- } \\
\text { summa } \\
\text { i Sverige, } \\
\text { mkr }\end{array}$ & \begin{tabular}{l|} 
genom- \\
snittliga \\
löneinkomst $\mathrm{i}$ \\
i Sverige
\end{tabular} & $\begin{array}{l}\text { löne- } \\
\text { summa } \\
\text { i Norge, } \\
\text { mkr }\end{array}$ & $\begin{array}{l}\text { genom- } \\
\text { snittliga } \\
\text { löneinkomst } \\
\text { i Norge }\end{array}$ \\
\hline Norge & 4291 & 341 & 79500 & 916 & 213500 & 1300 & 197 & 151500 & 38 & 29200 \\
\hline Sverige & 28285 & 3402 & 120275 & 3976 & 140558 & 13343 & 322 & 24167 & 2944 & 220694 \\
\hline
\end{tabular}

Personer som arbetar i ett grannland har ofta även inkomster i hemlandet. Man kan ha flyttat under året mellan länderna eller ha kombinerat sin anställning i det ena landet med ett extra jobb i det andra landet. Även bland personer som hade löneinkomst i båda länderna råder en viss obalans mellan svenskar och norrmän, då svenskar som arbetade $\mathrm{i}$ Norge hade högre genomsnittlig inkomst i Norge än vad de hade i hemlandet. För norrmännen var det tvärtom d.v.s. de hade högre genomsnittlig inkomst i hemlandet jämfört med vad de hade i Sverige. Svenskar som arbetade i Norge verkar ha en mer stadigvarande arbetsrelation med sin norska arbetsgivare än vad norrmännen i Sverige har.

Att det är den norska arbetsmarknaden som är mer intressant för svenskar än tvärtom blir ännu tydligare när vi ser antalet som klassificerats som arbetspendlare över riksgräns i respektive land. I detta fall står svenskar i Norge för drygt 92 procent av gränsöverskridandet. För dessa grupper ser inkomstfördelningen mellan arbetsland och bostadsland mer lika ut. Se tabell 1.

En delförklaring till varför så många svenskar arbetar i Norge och så få norrmän arbetar i Sverige kan vara att Oslo som huvudstadsregion har ett väl utvecklat näringsliv och att den ligger relativt nära riksgränsen mot Sverige medan de svenska gränsregionerna mot Norge är glest bebodda och har i huvudsak ett svagt utvecklat näringsliv. Men det finns rimligen även andra förklaringar till obalansen mellan länderna. T.ex. att balansen mellan utbud och efterfrågan av arbetskraft i olika branscher skiljer sig åt mellan länderna, vilket även påverkar lönenivåerna. En sådan slutsats kan dras utifrån att endast hälften av alla löneinkomsttagare bor i fylken eller län som ansluter till riksgränsen mellan de båda länderna. Ungefär en tredjedel bor eller har sitt arbete i någon av huvudstadsregionerna. Övriga ca 20 procent bor eller arbetar i ett län eller fylke som ligger långt från gränsområdet. Samtliga län respektive fylken har arbetstagare från grannlandet eller boende som arbetar i grannlandet. 


\section{Arbetskraftsrörlighet mellan Sverige och Norge}

\section{Inledning}

Rörligheten mellan nationella arbetsmarknader kan beskrivas utifrån olika betraktelsesätt exempelvis genom:

- löneinkomster/löntagareinkomster

- antalet löntagare

- förvärvsarbetande som arbetspendlare över riksgräns

- $\quad$ studerande över riksgräns

- flyttare

Projektet Nordisk pendlingskarta utgår från arbetsmarknads- och rörlighetsperspektiv, d.v.s. rörlighet över riksgräns relaterat till förvärvsarbete. Denna rapport redovisar antalet personer i Norge och i Sverige som under 2001 har haft en löneinkomst/lønnsinntekt i grannlandet och vilka av dessa personer som har klassificerats som "arbetspendlare över riksgräns". Redovisningen omfattar även lönesumman för löneinkomsttagarna och för arbetspendlarna över riksgräns. Dessutom redovisas bakgrundsvariabler som kön, ålder, utbildningsnivå och näringsgren.

\subsection{Populationsavgränsning}

Populationen i undersökningen utgörs av personer som har erhållit löneutbetalningar under 2001 från en arbetsgivare i grannlandet. Det innebär att en person som är folkbokförd i Sverige och som arbetar för ett svenskt företag i Norge och som får lönen av sin arbetsgivare i Sverige inte ingår i redovisningen. Företagare som utför arbete i grannlandet för sin egen firma ingår inte heller i redovisningen eftersom det inte heller för denne skapas någon kontrolluppgift för detta arbete.

I föreliggande rapport redovisas två olika populationer. Den ena avser löneinkomsttagare och den andra arbetspendlare över riksgräns.

Löneinkomsttagare/lønnsinntekttagare är personer som haft minst en löneinkomst under ett visst år enligt kontrolluppgifter i arbetslandet.

Arbetpendlare över riksgräns är personer som haft ett lönearbete under minst 4 timmar i november månad i arbetslandet under ett visst år. Personens eventuella inkomst $\mathrm{i}$ hemlandet för det aktuella kalenderåret får dock inte överstiga den i arbetslandet. Antalet arbetspendlare är en delmängd av antalet löneinkomsttagare. 


\subsection{Befolkningsfördelning i gränsområdet mellan Sverige och Norge}

Befolkningstätheten i anslutning till riksgränsen mellan två länder påverkar naturligtvis storleken på utbytet av arbetskraft mellan två länder. Det finns även andra aspekter som är viktiga för ett sådant utbyte som t.ex. legala, språkliga och kulturella förutsättningar. Även utbyggnaden av kommunikationer över riksgränsen spelar en väsentlig roll.

Gränsområdena mellan Sverige och Norge är med ett undantag glest bebodda. Det sydligaste området som omfattar Østfold, Akershus och Hedmarks fylke på den norska sidan samt Västra Götalands län och Värmlands län på den svenska är relativ tätbebodda. Även Oslo som utgör det norska huvudstadsområdet ligger relativt nära gränsen mellan de båda länderna. På den svenska sidan ligger befolkningskoncentrationerna främst i Västra Götalands län och då inte de områden som ligger nära gränsen till Norge. Även i Värmland är gränsområdet relativt glest bebott. Övriga gränsområden mellan Sverige och Norge löper genom fjällkedjan med mycket låg befolkningstäthet särskilt på den svenska sidan om gränsen.

Befolkningsfördelningen innebär att de svenskar som bor i gränsregionen har närmare till områden i Norge med väl utvecklat näringsliv, som kan erbjuda betydligt fler arbetsuppgifter och med ett bredare arbetsinnehåll. Det innebär att de norrmän som bor i det södra gränsområdet har närhet till en stor inhemsk arbetsmarknad medan arbetsmarknaden i det gränsnära området på den svenska sidan av gränsen är liten både till storlek och till bredden på arbetsuppgifter. 


\section{Statistikbyråernas förutsättningar}

Genom att statistiksystemen i de nordiska länderna till stora delar är registerbaserade finns förutsättningar för att framställa regional pendlingsstatistik över riksgräns. Det innebär inte att det har varit enkelt att hitta lösningar för att sambearbeta material från de olika länderna. Varje land har sin uppläggning av statistiken och skillnaderna har blivit tydliga i detta samarbete. Olikheterna har varit möjliga att hantera.

Personnumret är vanligtvis nyckeln till att sambearbeta individuppgifter från olika register. Denna förutsättning är inte tillgänglig eftersom det saknas ett gemensamt nordiskt personnummer. Det innebär att en person som bor i Norge och arbetar i Sverige har ett personnummer i Norge och ett annat i Sverige. De delar av personnumret som avser födelsedatum har dock kunnat användas. Ett annat problem som projektet har haft att lösa är att lagstiftningen i berörda länder inte tillåter att personnummeranknutna uppgifter utlämnas utanför landets gränser. Däremot har födelsedatum, år, månad och dag samt namn kunnat utlämnas, vilket möjliggjort identifiering av personer i det andra landet.

Någon särskild datainsamling har inte gjorts för att kunna genomföra projektet. Underlaget utgörs helt av de administrativa data som finns tillgängliga i respektive land. De uppgifter som används för att definiera de två huvudpopulationer som ingår i undersökningen består främst av de kontrolluppgifter som arbetsgivarna lämnar till skattemyndigheterna och av uppgifter från de centrala befolkningsregistren.

Utbytet av material har omfattat födelsedatum, löpnummer och namn på de inkomsttagare i Sverige som inte är folkbokförda i Sverige och på motsvarande sätt för de inkomsttagare i Norge som inte är folkbokförda i Norge. Genom sambearbetning av uppgift om födelsedatum och namn har sedan de aktuella personerna kunnat identifieras i det mottagande landet.

Projektet Nordisk pendlingskarta berör inte den nationella officiella sysselsättningsstatistiken. I denna finns en underskattning av dels antalet personer som har förvärvsarbete i landet (dagbefolkning), dels av antalet förvärvsarbetande personer som är folkbokförda i landet (nattbefolkning). I kommuner som Strömstad, Eda och Årjäng finns ett relativt stort antal personer som har sin inkomst i Norge. Dessa personer borde ingå som förvärvsarbetande i den svenska nattbefolkningen och i den norska dagbefolkningen. $\mathrm{Nu}$ redovisas dessa personer som ej förvärvsarbetande i svensk statistik och ingår överhuvudtaget inte i den norska sysselsättningsstatistiken. På motsvarande sätt sker redovisningen hos Statistiska Sentralbyrån i Norge av norrmän som arbetar i Sverige och svenskar som arbetar i Norge. 


\section{Rörlighet från Norge till Sverige}

Avsnitt 3 redovisar strömmen av personer som år 2001 var folkbokförda i Norge och som arbetade i Sverige. I redovisningen används genomgående de två begreppen löneinkomsttagare och arbetspendlare, vilka beskrivs närmare i kapitel 1 samt i bilaga 1. Det var totalt 4291 personer som bodde i Norge och hade lönearbete i Sverige under 2001. Av dessa personer var 1300 klassificerade som arbetspendlare. De norska löneinkomsttagarna tjänade tillsammans 341 miljoner kronor i Sverige. Deras genomsnittliga löneinkomsten i Sverige var ca 80000 SEK och drygt 200000 SEK i Norge.

De som klassificerades som arbetspendlare tjänade tillsammans 197 miljoner SEK. Deras genomsnittliga löneinkomst i Sverige var ca 150000 SEK och 30000 SEK i Norge.

Tabell 2. Personer folkbokförda i Norge med inkomster i Sverige år 2001 i SEK

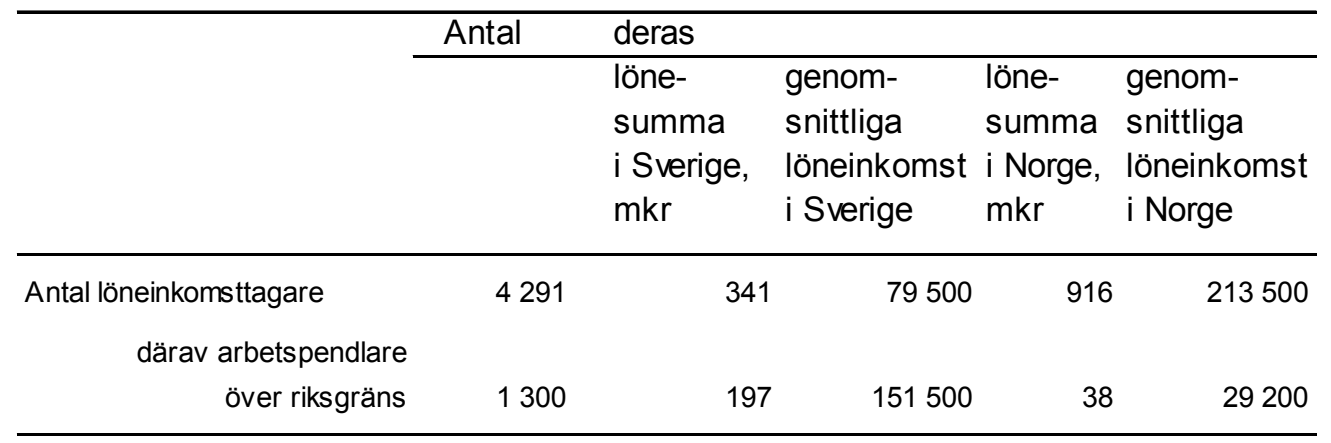

\section{1 Ålder}

60 procent av löneinkomsttagarna var män och 40 procent kvinnor. Av arbetspendlarna var 55 procent män och 45 procent kvinnor.

55 procent av löneinkomsttagarna och 60 procent av arbetspendlarna var yngre än 35 år. Antalet kvinnor dominerade i åldersgruppen 15-24 år. I åldersgrupperna därefter dominerade männen i antal med stigande ålder. 
Tabell 3a. Personer folkbokförda i Norge med inkomster i Sverige efter ålder och kön 2001

\begin{tabular}{|c|c|c|c|c|c|c|}
\hline \multirow[t]{2}{*}{ Âlder } & \multicolumn{2}{|c|}{ Löneinkomsttagare } & \multicolumn{4}{|c|}{ Arbetspendlare } \\
\hline & Män & Kvinnor & Totalt & Män & Kvinnor & Totalt \\
\hline $15-19$ & 165 & 242 & 407 & 76 & 116 & 192 \\
\hline $20-24$ & 373 & 465 & 838 & 112 & 142 & 254 \\
\hline $25-34$ & 630 & 493 & 1123 & 201 & 144 & 345 \\
\hline $35-44$ & 457 & 229 & 686 & 120 & 76 & 196 \\
\hline $45-54$ & 525 & 182 & 707 & 123 & 58 & 181 \\
\hline $55-59$ & 228 & 70 & 298 & 54 & 21 & 75 \\
\hline $60+$ & 187 & 45 & 232 & 40 & 17 & 57 \\
\hline Summa & 2565 & 1726 & 4291 & 726 & 574 & 1300 \\
\hline
\end{tabular}

Medianlönesumman ${ }^{1}$ för inkomsttagarna var ca 30000 SEK. För arbetspendlarna var den betydligt högre ca 100000 SEK. Den stora skillnaden i medianlön mellan inkomsttagare och arbetspendlare förklaras av att personen måste uppnå en viss inkomstnivå för att räknas som arbetspendlare och att löneinkomsten skall vara högre från arbetet $\mathrm{i}$ Sverige än det i Norge. Medianlönesumman ökar med stigande ålder upp till åldersgruppen 60 år och äldre

Medianlönesumman för kvinnor var något högre än för män i åldersgruppen under 20 år och över 59. I övriga åldersklasser var medianlönesumman för kvinnor betydligt lägre än för män.

Tabell 3b: Medianlönesumman år 2001 för inkomsttagare och arbetspendlare fördelade efter kön och ålder. SEK

\begin{tabular}{|c|c|c|c|c|c|c|}
\hline \multirow[t]{3}{*}{ Ålder } & \multicolumn{6}{|c|}{ Medianlönesumma } \\
\hline & \multicolumn{3}{|c|}{ Löneinkomsttagare } & \multicolumn{3}{|c|}{ Arbetspendlare } \\
\hline & Män & Kvinnor & Totalt & Män & Kvinnor & Totalt \\
\hline $15-19$ & 20452 & 21843 & 21108 & 37816 & 30464 & 32921 \\
\hline $20-24$ & 43231 & 25000 & 31762 & 73823 & 65927 & 69989 \\
\hline $25-34$ & 48145 & 34227 & 41669 & 137893 & 103312 & 123203 \\
\hline $35-44$ & 40000 & 31600 & 35240 & 203916 & 96772 & 141032 \\
\hline $45-54$ & 28165 & 24739 & 26270 & 222150 & 158425 & 193468 \\
\hline $55-59$ & 23031 & 17843 & 22255 & 237280 & 198173 & 217791 \\
\hline $60+$ & 12000 & 20005 & 13259 & 95851 & 79021 & 93126 \\
\hline Summa & 32141 & 25734 & 30262 & 116940 & 71441 & 99900 \\
\hline
\end{tabular}

${ }^{1}$ Medianlönesumman är den lönesumma som ligger i mitten när lönesummorna sorterats i storleksordning.. 


\subsection{Utbildning}

Utbildningsnivån är indelad i tre grupper 1, 2 och 3 samt gruppen 9. 85 procent av inkomsttagarna hade lägst gymnasial utbildning, tillhörde grupp 2 eller 3 . Av dessa utgjorde de med gymnasial utbildning 45 procentenheter och de med eftergymnasial utbildning 40 procentenheter. Bland de kvinnliga löneinkomsttagarna hade drygt 50 procent gymnasieutbildning medan motsvarande andel för männen var drygt 40 procent. Andelen kvinnor med eftergymnasial utbildning var drygt 30 procent medan motsvarande andel för männen var knappt 45 procent.

Andelen arbetspendlare med lägst gymnasieutbildning var 80 procent varav knappt 60 procentenheter hade gymnasial utbildning och drygt 20 procentenheter hade eftergymnasial utbildning. Utbildningsnivån var således betydligt lägre bland dem som arbetspendlade än för hela gruppen löneinkomsttagare. Bland arbetspendlarna hade drygt 60 procent av kvinnorna gymnasial utbildning jämfört med drygt 50 procent för männen. 20 procent av de kvinnor som arbetspendlade hade eftergymnasial utbildning jämfört med 25 procent för männen. Männen hade således något högre utbildning än kvinnorna.

Tabell 4a: Antal inkomsttagare respektive arbetspendlare efter utbildningsnivå och kön 2001.

\begin{tabular}{lrrrrrr}
\hline Utbildning & \multicolumn{2}{c}{ Löneinkomsttagare } & \multicolumn{4}{c}{ Arbetspendlare } \\
& Män & Kvinnor & Totalt & Män & Kvinnor & Totalt \\
\hline 1 & 213 & 153 & 366 & 98 & 75 & 173 \\
2 & 1062 & 899 & 1961 & 388 & 350 & 738 \\
3 & 1127 & 556 & 1683 & 181 & 114 & 295 \\
9 & 163 & 118 & 281 & 59 & 35 & 94 \\
\multirow{2}{*}{ Summa } & 2565 & 1726 & 4291 & 726 & 574 & 1300 \\
\hline
\end{tabular}

Medianlönesumman för inkomsttagarna var högst för gruppen med okänd utbildning och för personer med gymnasial utbildning. Medianlönesumman för dessa grupper låg omkring 35000 SEK. Se tabell 4b. Den klart lägsta medianlönesumman, 17000 SEK, hade personer med eftergymnasial utbildning.

För arbetspendlarna var medianlönesumman högst för de med eftergymnasial utbildning 160000 SEK. Skillnaden mellan män och kvinnor var stor, männens medianlönesumma var på 208000 SEK och kvinnornas 120000 SEK. Männen hade högre medianlönesumman än kvinnorna i alla grupper och skillnaden ökade med utbildningsnivån.

2 Indelningen bygger på ISCED 97. Utbildningsgrupp 1 omfattar förgymnasial utbildning, grupp 2 gymnasial utbildning i högst tre år och grupp 3 avser eftergymnasial utbildning inklusive 4-årig gymnasial utbildning. I grupp 9 ingår personer för vilka utbildningsnivån är okände. 
Tabell 4b: Medianlönesumman i SEK för löneinkomsttagare och arbetspendlare efter utbildningsnivå år 2001

\begin{tabular}{|c|c|c|c|c|c|c|}
\hline \multirow[t]{3}{*}{ Utbildning } & \multicolumn{6}{|c|}{ Medianlönesumma } \\
\hline & \multicolumn{3}{|c|}{ Löneinkomsttagare } & \multicolumn{3}{|c|}{ Arbetspendlare } \\
\hline & Män & Kvinnor & Totalt & Män & Kvinnor & Totalt \\
\hline 1 & 37982 & 29344 & 34408 & 88621 & 73591 & 82051 \\
\hline 2 & 45670 & 29388 & 36982 & 97790 & 60874 & 75119 \\
\hline 3 & 16952 & 17369 & 17000 & 208108 & 120936 & 163349 \\
\hline 9 & 51406 & 37130 & 43729 & 115908 & 77351 & 103873 \\
\hline Summa & 32141 & 25734 & 30262 & 116940 & 71441 & 99900 \\
\hline
\end{tabular}

\subsection{Näringsgren ${ }^{3}$}

Den allra största delen av löneinkomsttagarna och arbetspendlarna arbetade inom tjänstesektorn. Denna andel uppgick till 89 respektive 87 procent medan 10 respektive 12 procent arbetade inom tillverkningsindustri och byggverksamhet. Bland kvinnorna arbetade 95 procent inom tjänstenäringar medan motsvarande andel för männen var 85 procent för löneinkomsttagarna och 80 procent för arbetspendlarna. Se tabell 5a.

18 procent av löneinkomsttagarna och 28 procent av arbetspendlarna var sysselsatta inom Parti- och detaljhandel. Inom Hälso- och sjukvård m.m. arbetade 17 procent av löneinkomsttagarna och 14 procent av arbetspendlarna samt inom Fastighets- och uthyrningsverksamhet med företagstjänster arbetade 15 procent av löneinkomsttagarna och 13 procent av arbetspendlarna.

\footnotetext{
${ }^{3}$ Redovisning näringsgren följer EU:s näringsgrensstandard NACE Rev 1. Redovisningen sker på ensiffernivå, vilken omfattar 17 avdelningar.
} 
Tabell 5a: Antal löneinkomsttagare och arbetspendlare efter näringsgren och kön 2001

\begin{tabular}{|c|c|c|c|c|c|c|}
\hline \multirow[t]{2}{*}{ Näringsgren } & \multicolumn{3}{|c|}{ Löneinkomsttagare } & \multicolumn{3}{|c|}{ Arbetspendlare } \\
\hline & Män & Kvinnor & Totalt & Män & Kvinnor & Totalt \\
\hline Jordbruk, jakt och skogsbruk & 25 & 9 & 34 & 12 & 0 & 12 \\
\hline Fiske & .. & .. & .. & .. & .. & .. \\
\hline Utvinning &.. & .. & .. & .. & .. & .. \\
\hline Tillverkning & 285 & 73 & 358 & 101 & 24 & 125 \\
\hline El, -gas-, värme- och vattenförsörjning & 12 & 3 & 15 & 4 & 0 & 4 \\
\hline Byggverksamhet & 74 & 6 & 80 & 29 & 3 & 32 \\
\hline Partihandel och detaljhandel & 387 & 381 & 768 & 178 & 187 & 365 \\
\hline Hotell- och restaurantverksamhet & 147 & 165 & 312 & 57 & 61 & 118 \\
\hline Transp, magasinering och kommunik. & 191 & 70 & 261 & 66 & 22 & 88 \\
\hline Finansiell verksamhet & 49 & 27 & 76 & 15 & 8 & 23 \\
\hline Fastighet- och uthyr.verksh, företagstj & 431 & 207 & 638 & 97 & 68 & 165 \\
\hline Offentlig förvaltning och försvar & 120 & 55 & 175 & 22 & 15 & 37 \\
\hline Utbildning & 324 & 162 & 486 & 20 & 26 & 46 \\
\hline Hälso- och sjukv, soc. tjänster & 288 & 422 & 710 & 66 & 119 & 185 \\
\hline Andra samhälleliga och personl. tjänst. & 204 & 137 & 341 & 53 & 40 & 93 \\
\hline Förvärvsarbete i hushåll & 0 & 0 & 0 & 0 & 0 & 0 \\
\hline Verksamhet vid int. org., utl. ambassad & 0 & 0 & 0 & 0 & 0 & 0 \\
\hline Okänt & 26 & 9 & 35 & 6 & 1 & 7 \\
\hline Summa & 2563 & 1726 & 4289 & 726 & 574 & 1300 \\
\hline
\end{tabular}

De högsta medianlönesumman för löneinkomsttagare, 75000 SEK, hade Transport, magasinering och kommunikation. Se tabell $5 \mathrm{~b}$. Bland arbetspendlarna var medianlönesumman för dem som arbetade inom Offentlig förvaltning och försvar inte fullt 260000 SEK, för Tillverkningsindustri 190000 SEK samt för Transport, magasinering och kommunikation inte fullt 190000 SEK. I de två branscher som hade flest arbetspendlare, Partihandel och detaljhandel samt Hälso- och sjukvård m.m. låg medianlönesumman på ca 70000 SEK 
Tabell 5b. Medianlönesumma 2001 efter näringsgren fördelad efter kön

\begin{tabular}{|c|c|c|c|c|c|c|}
\hline \multirow[t]{3}{*}{ Näringsgren } & \multicolumn{6}{|c|}{ Medianlönesumma } \\
\hline & \multicolumn{2}{|c|}{ Inkomsttagare } & \multicolumn{4}{|c|}{ Arbetspendlare } \\
\hline & Män & Kvinnor & Totalt & Män & Kvinnor & Totalt \\
\hline Jordbruk, jakt och skogsbruk & 28560 & 2342 & 14505 & 39890 & 0 & 39890 \\
\hline Fiske & .. &.. & .. & .. & .. & .. \\
\hline Utvinning & .. & .. & .. & .. & .. & .. \\
\hline Tillverkning & 77006 & 31122 & 62483 & 213554 & 83595 & 190654 \\
\hline El, -gas-, värme- och vattenförsörjning & 41242 & 14659 & 32162 & 131381 & 0 & 131381 \\
\hline Byggverksamhet & 53229 & 31159 & 50642 & 106151 & 89544 & 101461 \\
\hline Partihandel och detaljhandel & 45875 & 36982 & 42220 & 70620 & 70533 & 70533 \\
\hline Hotell- och restaurantverksamhet & 26076 & 25603 & 25627 & 79959 & 51438 & 60475 \\
\hline Transp, magasinering och kommunik. & 77035 & 69516 & 75777 & 203497 & 128892 & 187034 \\
\hline Finansiell verksamhet & 40000 & 30199 & 31245 & 256365 & 34130 & 150576 \\
\hline Fastighet- och uthyr.verksh, företagstj & 24034 & 24500 & 24473 & 170026 & 111487 & 131006 \\
\hline Offentlig förvaltning och försvar & 14720 & 22100 & 20723 & 275561 & 218386 & 258120 \\
\hline Utbildning & 6000 & 7595 & 6592 & 107029 & 87412 & 98780 \\
\hline Hälso- och sjukv, soc. tjänster & 50393 & 24608 & 30270 & 126851 & 62315 & 72333 \\
\hline Andra samhälleliga och personl. tjänst. & 23892 & 17374 & 20784 & 84000 & 54218 & 72562 \\
\hline Förvärvsarbete i hushåll & 0 & 0 & 0 & 0 & 0 & 0 \\
\hline Verksamhet vid int. org., utl. ambassad & 0 & 0 & 0 & 0 & 0 & 0 \\
\hline Okänt & 21659 & 16995 & 20000 & 122909 & 243201 & 163349 \\
\hline Summa & 32141 & 25734 & 30262 & 116940 & 71441 & 99900 \\
\hline
\end{tabular}

\subsection{Sektor}

Sektorsindelningen belyser ägarstrukturen bland företag och organisationer, Här sker redovisningen i två grupper nämligen Offentlig förvaltning och service samt Näringslivet inklusive offentliga bolag.

Två tredjedelar av inkomsttagarna och drygt 80 procent av arbetspendlarna arbetade inom näringslivet. De relativt få arbetspendlarna som arbetade inom offentlig sektor hade sin huvudsakliga verksamhet inom vård och omsorg.

Tabell 6a. Antal löneinkomsttagare och arbetspendlare efter sektor 2001 fördelade efter kön.

\begin{tabular}{lrrrrrr}
\hline Sektor & \multicolumn{2}{c}{ Löneinkomsttagare } & \multicolumn{3}{c}{ Arbetspendlare } \\
& Män & Kvinnor & Totalt & Män & Kvinnor & Totalt \\
\hline Offentlig förvaltning och service & 802 & 587 & 1389 & 103 & 136 & 239 \\
Näringslivet inkl. offentliga bolag & 1763 & 1139 & 2902 & 623 & 438 & 1061 \\
Summa & 2565 & 1726 & 4291 & 726 & 574 & 1300 \\
\hline
\end{tabular}

Medianlönesumman efter sektor var för löneinkomsttagare högst i näringslivet med 40 000 SEK, i offentlig sektor var den 14000 SEK. För arbetspendlarna var medianlönesumman däremot högst inom Offentlig sektor med 103000 SEK jämfört med 89000 SEK inom Näringslivet. 
En liknande fördelning erhålls om lönesumman fördelas efter kön. Medianlönesumman var högre i näringslivet både för manliga och kvinnliga löneinkomsttagare medan både manliga och kvinnliga arbetspendlarna hade högst medianlönesumma i offentlig sektor. Männen hade dessutom högre medianlönesumma än kvinnorna i alla grupper utom i gruppen löneinkomsttagare i offentlig förvaltning och service.

Tabell 6b. Medianlön i SEK för löneinkomsttagare och arbetspendlare efter sektor 2001

\begin{tabular}{|c|c|c|c|c|c|c|}
\hline \multirow[t]{2}{*}{ Sektor } & \multicolumn{6}{|c|}{ Medianlönesumma } \\
\hline & Män & Kvinnor & Totalt & Män & Kvinnor & Totalt \\
\hline Offentlig förvaltning och service & 9414 & 18810 & 13575 & 154565 & 72011 & 103328 \\
\hline Näringslivet inkl. offentliga bolag & 47827 & 30912 & 39942 & 111445 & 71290 & 89153 \\
\hline Summa & 32141 & 25734 & 30262 & 116940 & 71441 & 99900 \\
\hline
\end{tabular}

\subsection{Födelseregion}

Löneinkomsttagarna respektive arbetspendlarnas födelseland har grupperats på tre regioner, Norge, Sverige och övriga.

Födelseregion Norge var den största, följt av Sverige, i dessa två födelseregioner återfanns mer än 90 procent av den studerade populationen. Från övriga länder kom lite mer än 400 personer. Männen var fler än kvinnorna i alla grupper, särskilt stor var skillnaden för de med födelseregion Norge.

Mönstret för arbetspendlarna var ungefär detsamma som för inkomsttagarna. Norge följt av Sverige var de två klart största födelseregionerna med 691 respektive 491 st. av totalt 1300 arbetspendlare.

Tabell 7a. Antal inkomsttagare och arbetspendlare efter födelseregion och kön

\begin{tabular}{lrrrrrr}
\hline Födelseregion & \multicolumn{2}{c}{ Löneinkomsttagare } & \multicolumn{4}{c}{ Arbetspendlare } \\
& Män & Kvinnor & Totalt & Män & Kvinnor & Totalt \\
\hline Norge & 1403 & 767 & 2170 & 394 & 297 & 691 \\
Sverige & 895 & 816 & 1711 & 256 & 235 & 491 \\
Övriga & 267 & 143 & 410 & 76 & 42 & 118 \\
Summa & 2565 & 1726 & 4291 & 726 & 574 & 1300 \\
\hline
\end{tabular}

Högsta medianlönesumman för inkomsttagarna hade de som var födda i Sverige med 34 000 SEK. Gruppen övriga hade högst medianlönesumma bland arbetspendlarna, 100 000 SEK. Se tabell 7 b. 
Tabell 7b. Medianlönesumma i SEK för löneinkomsttagare och arbetspendlare efter födelseregion 2001

\begin{tabular}{|c|c|c|c|c|c|c|}
\hline \multirow[t]{3}{*}{ Födelseregion } & \multicolumn{6}{|c|}{ Medianlönesumma } \\
\hline & \multicolumn{2}{|c|}{ Löneinkomsttagare } & \multicolumn{4}{|c|}{ Arbetspendlare } \\
\hline & Män & Kvinnor & Totalt & Män & Kvinnor & Totalt \\
\hline Norge & 24824 & 24803 & 24814 & 118011 & 76966 & 91411 \\
\hline Sverige & 45243 & 27429 & 34427 & 119580 & 65695 & 89544 \\
\hline Övriga & 30000 & 35951 & 31607 & 100006 & 106981 & 100006 \\
\hline Summa & 32141 & 25734 & 30262 & 116940 & 71441 & 99900 \\
\hline
\end{tabular}

\subsection{Regional fördelning}

Riksgränsen mellan Sverige och Norge är lång och löper mestadels genom glest bebodda fjällområden. Den sydligaste delen av riksgränsen löper dock längs relativt tätbefolkade fylken och län som Østfold, Akershus och Hedmarks fylke på den norska sidan samt Västra Götalands län och Värmlands län på den svenska. De fylken som ligger i de glest bebodda gränsområdena är Sør-Trøndelag, Nord-Trøndelag, Nordland och Troms. Motsvarande regioner på den svenska sidan är Jämtlands, Västerbottens och Norrbottens län.

\section{Löneinkomsttagare}

Totalt 4291 personer med folkbokföringsadress i Norge hade en svensk löneinkomst under 2001. Se tabell 6a. Drygt 60 procent av dessa var bosatta i någon av de tätbefolkade fylkena i södra Norge främst i Oslo kommun samt Østfolds och Akershus fylken. De svenska län som hade de flesta inkomsttagarna från Norge var Västra Götalands län och Stockholms län. Från dessa två län fick 50 procent av de norrmän med löneinkomst i Sverige sin svenska inkomst. Andra län med relativt många inkomsttagare från Norge var Värmlands län med drygt 300, Skåne län och Uppsala län med drygt 200 inkomsttagare.

\section{Arbetspendlare}

Av dem som var folkbokförda i Norge och hade en löneinkomst i Sverige under 2001 klassades 1300 som arbetspendlare d.v.s. de arbetade i november i Sverige och de hade den största löneinkomsten under året i Sverige. Hälften av dessa personer var folkbokförda i fylken som ligger längs den svenska gränsen och drygt 30 procent var folkbokförda i Oslo. Knappt 20 procent var folkbokförda i övriga fylken.

Arbetspendlarna hade arbete i alla delar av Sverige. Samtliga län och fylken berördes av arbetspendlare från Norge. 40 procent pendlade till Västra Götalands län. 20 procent till övriga län som gränsar till Norge. Drygt 20 procent arbetspendlade till Stockholms län och till övriga 14 län pendlade knappt 20 procent. 
Andelen arbetspendlare av samtliga löneinkomsttagare

Andelen arbetspendlarna av samtliga löneinkomsttagare som var folkbokförda i Norge 2001 och som hade löneinkomst i Sverige är en indikator på graden av traditionell pendling. Den största andelen arbetspendlare berörde gränsregioner som Østfold, Hedmark och Nord-Trøndelag på den norska sidan och Jämtland, Västra Götaland och Värmland på den svenska.

Tabell 8a. Antal personer folkbokförda i Norge och som hade löneinkomst i Sverige 2001 fördelade efter bostadsfylke

\begin{tabular}{lccc}
\hline Bostadsfylke & $\begin{array}{l}\text { Antal } \\
\text { inkomst- } \\
\text { tagare }\end{array}$ & $\begin{array}{l}\text { därav } \\
\text { arbets- } \\
\text { pendlare }\end{array}$ & $\begin{array}{c}\text { Andel } \\
\text { arbets- } \\
\text { pendlare }\end{array}$ \\
\hline 01 Østfold & 653 & 353 & 54,1 \\
02 Akershus & 627 & 148 & 23,6 \\
04 Hedmark & 211 & 112 & 53,1 \\
16 Sør-Trøndelag & 264 & 51 & 19,3 \\
17 Nord-Trøndelag & 101 & 51 & 50,5 \\
18 Nordland & 111 & 40 & 36,0 \\
19 Troms & 107 & 26 & 24,3 \\
Summa gränsfylken & $\mathbf{2 0 7 4}$ & $\mathbf{7 8 1}$ & $\mathbf{3 7 , 7}$ \\
& & & \\
03 Oslo & $\mathbf{1 3 8 5}$ & $\mathbf{3 0 1}$ & $\mathbf{2 1 , 7}$ \\
Övriga Fylken & $\mathbf{8 3 2}$ & $\mathbf{2 1 8}$ & $\mathbf{2 6 , 2}$ \\
Totalt & & & $\mathbf{3 0 , 3}$ \\
\hline
\end{tabular}

Tabell 8b. Personer folkbokförda i Norge och som hade löneinkomst i Sverige 2001 fördelade efter arbetslän

\begin{tabular}{lccc}
\hline Arbetslän & $\begin{array}{l}\text { Antal } \\
\text { inkomst- } \\
\text { tagare }\end{array}$ & $\begin{array}{l}\text { därav } \\
\text { arbets- } \\
\text { pendlare }\end{array}$ & $\begin{array}{c}\text { Andel } \\
\text { arbets- } \\
\text { pendlare }\end{array}$ \\
\hline Västra Götalands län & 1267 & 493 & 38,9 \\
Värmlandslän & 334 & 129 & 38,6 \\
Dalarnas län & 102 & 29 & 28,4 \\
Jämtlands län & 152 & 71 & 46,7 \\
Västerbottens län & 95 & 23 & 24,2 \\
Norrbottens län & 147 & 34 & 23,1 \\
Summa gränslän & $\mathbf{2 0 9 7}$ & $\mathbf{7 7 9}$ & $\mathbf{3 7 , 1}$ \\
Stockholms län & $\mathbf{1 0 1 5}$ & $\mathbf{2 6 6}$ & $\mathbf{2 6 , 2}$ \\
Övriga län & $\mathbf{1 1 7 9}$ & $\mathbf{2 5 5}$ & $\mathbf{2 1 , 6}$ \\
Totalt & & & $\mathbf{3 0 , 3}$ \\
\hline
\end{tabular}




\subsubsection{Gränsregioner}

Över riksgränsen mellan Sverige och Norge löper tre definierade gränsregioner som erhåller stöd från EU:s Interreg 3-program. De heter Gränslöst samarbete, Inre Skandinavien och Nordens gröna bälte.

\section{Gränslöst samarbete}

Gränslöst samarbete är den sydligaste av de tre regionerna. Den omfattar 9 kommuner i Østfolds fylke och 13 kommuner i Västra Götalands län.

Det fanns knappt 500 personer i den norska delen av Gränslöst samarbete som hade löneinkomst inom den svenska delen av regionen. Drygt 80 procent av dessa bodde och hade sin inkomst från en gränskommun. Av de ca 500 inkomsttagarna var ca 300 arbetspendlare. Se tabell 8.

Tabell 9. Personer folkbokförda i norska gränsregioner och som hadelöneinkomst i motsvarande gränsregion i Sverige 2001

\begin{tabular}{lccc}
\hline Arbetsregion & $\begin{array}{l}\text { Antal } \\
\text { Inkomst- } \\
\text { tagare }\end{array}$ & $\begin{array}{c}\text { Arbets- } \\
\text { pendlare }\end{array}$ & $\begin{array}{c}\text { Andel arbets- } \\
\text { pendlare i \% } \\
\text { av inkomsttagare }\end{array}$ \\
\hline $\begin{array}{l}\text { Gränslöst samarbete } \\
\text { därav Gränskommun }\end{array}$ & 404 & 253 & 60,5 \\
Inre Skandinavien & 148 & 94 & 63,1 \\
därav Gränskommun & 113 & 85 & 63,5 \\
& 101 & 53 & 75,2 \\
Nordens gröna bälte & 57 & 40 & 52,5 \\
därav Gränskommun & & & 70,2 \\
Totalt gränsregioner & 733 & 440 & 60,0 \\
därav gränskommun & 574 & 380 & 66,2 \\
\hline
\end{tabular}

Inre Skandinavien

Inre Skandinavien omfattar Värmlands län, Malungs och Älvdalens kommuner i Dalarna, Hedmarks fylke samt delar av Akershus och Østfolds fylke. Totalt ingår 58 kommuner i regionen varav 18 av dessa är belägna i Sverige och 40 i Norge.

Det fanns ca 150 personer i den norska delen av regionen som hade löneinkomst inom den svenska delen av Inre Skandinavien. 75 procent av dessa bodde och hade sin löneinkomst från en gränskommun. Av de ca 150 inkomsttagarna var drygt 90 arbetspendlare.

\section{Nordens gröna bälte}

Nordens gröna bälte omfattar Jämtlands län samt Nord-Tröndelags och Sör-Tröndelags fylken. Regionen omfattar 57 kommuner. 
Ca 100 personer i den norska delen av Nordens gröna bälte hade löneinkomst inom den svenska delen av regionen. Knappt 60 procent av dessa bodde och hade sin löneinkomst från en gränskommun. Av de ca 100 inkomsttagarna var ca 50 arbetspendlare.

\subsection{Lönesummor}

Av samtliga norska löneinkomsttagare i Sverige under 2001 hade drygt 57 procent en större löneinkomst i hemlandet än vad de hade i Sverige. De är svårt att utifrån befintligt material försöka ge en entydig förklaring varför så många norrmän tar jobb av tillfällig natur på den svenska arbetsmarknaden.

I diagram 1 redovisas löneinkomstagarnas lönesummor fördelade på deciler. De 10 procent av som tjänade mest i Sverige hade, enligt staplarna i decil 10, tillsammans ca 170 miljoner kronor i inkomster i Sverige och drygt 80 miljoner kronor i Norge omräknat till svensk valuta. I övriga deciler har löneinkomsttagarna tjänat mer i sitt hemland. Det är en stor del av förklaringen till att bara 30 procent av inkomsttagarna klassificerade som arbetspendlare över riksgräns.

\section{Diagram 1. Norska löneinkomsttages decillönesummor 2001. I miljoner SEK}

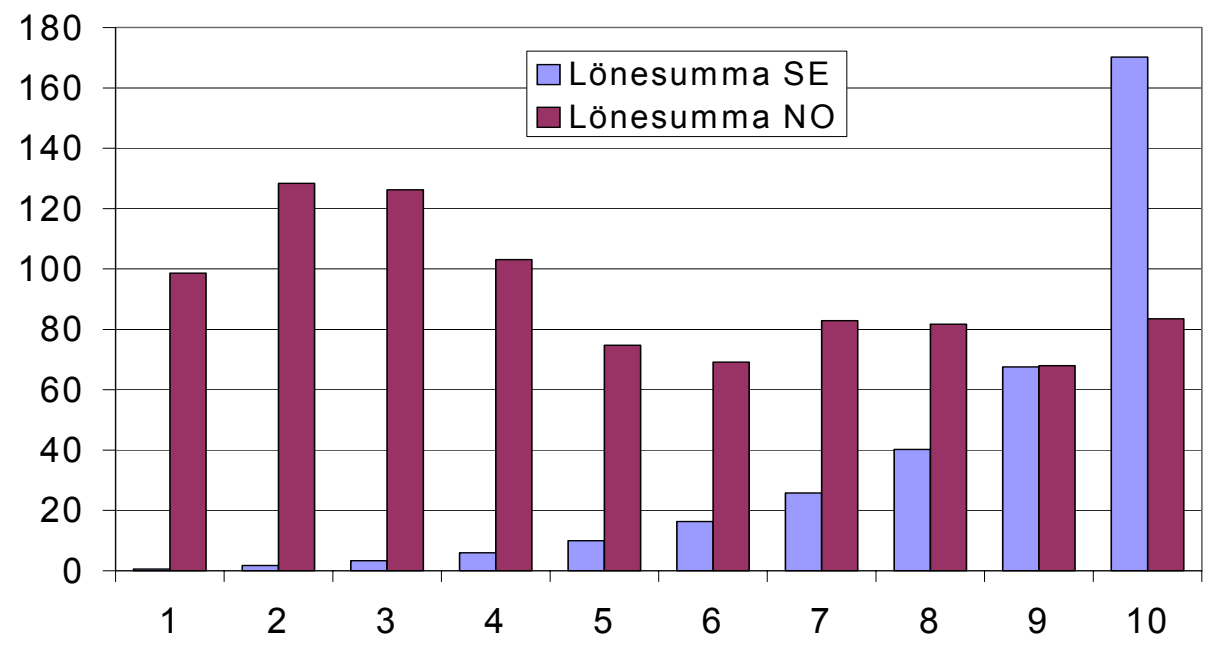

\section{Näringsgren}

Totalt tjänade personer folkbokförda i Norge ca 341 miljoner kronor i Sverige under 2001 enligt de svenska kontrolluppgifterna. Därav tjänade de som klassificerades som arbetspendlare över riksgräns drygt 197 miljoner kronor. 
Tabell 10. Lönesummor fördelade på näringsgren 2001. 1000-tal SEK

\begin{tabular}{|c|c|c|c|c|c|c|}
\hline \multirow[t]{3}{*}{ Näringsgren } & \multicolumn{6}{|c|}{ Total lönesumma } \\
\hline & \multicolumn{3}{|c|}{ Inkomstagare } & \multicolumn{3}{|c|}{ Arbetspendlare } \\
\hline & Män & Kvinnor & Totalt & Män & Kvinnor & Totalt \\
\hline Jordbruk, jakt och skogsbruk & 1275648 & 68091 & 1343739 & 855639 & 0 & 855639 \\
\hline Fiske & .. & . & .. & . & .. & .. \\
\hline Utvinning & .. & .. & .. & .. & .. & .. \\
\hline Tillverkning & 40567870 & 5932662 & 46500532 & 23417592 & 3353217 & 26770809 \\
\hline El, -gas-, värme- och vattenförsörjning & 1052343 & 46320 & 1098663 & 554760 & 0 & 554760 \\
\hline Byggverksamhet & 6780044 & 280081 & 7060125 & 3589199 & 212327 & 3801526 \\
\hline Partihandel och detaljhandel & 38836460 & 24623356 & 63459816 & 24831512 & 17297193 & 42128705 \\
\hline Hotell- och restaurantverksamhet & 8617468 & 6977871 & 15595339 & 5881060 & 4315615 & 10196675 \\
\hline Transp, magasinering och kommunik. & 25887489 & 6719689 & 32607178 & 15860478 & 3738251 & 19598729 \\
\hline Finansiell verksamhet & 12838136 & 1982808 & 14820944 & 7675224 & 900958 & 8576182 \\
\hline Fastighet- och uthyr.verksh, företagstj & 44019407 & 17020759 & 61040166 & 25595943 & 10644353 & 36240296 \\
\hline Offentlig förvaltning och försvar & 8568588 & 4095179 & 12663767 & 5673012 & 2863453 & 8536465 \\
\hline Utbildning & 7947927 & 5728172 & 13676099 & 2957955 & 2518999 & 5476954 \\
\hline Hälso- och sjukv, soc. tjänster & 25199426 & 22712013 & 47911439 & 11298444 & 10902983 & 22201427 \\
\hline Andra samhälleliga och personl. tjänst. & 14245236 & 6631197 & 20876433 & 6852456 & 4382664 & 11235120 \\
\hline Förvärvsarbete i hushåll & 0 & 0 & 0 & 0 & 0 & 0 \\
\hline Verksamhet vid int. org., utl. ambassad & 0 & 0 & 0 & 0 & 0 & 0 \\
\hline Okänt & 2007315 & 469476 & 2476791 & 925356 & 243201 & 1168557 \\
\hline Summa & 237843357 & 103287674 & 341131031 & 135968630 & 61373214 & 197341844 \\
\hline
\end{tabular}

Lönesummornas fördelning visar på en koncentration till Tillverkning, Parti- och detaljhandel, Fastighets- och uthyrningsverksamhet med företagstjänster samt Hälsooch sjukvård m.m.. Dessa fyra näringar står för nästan två tredjedelar av lönesumman.

Tabell 11. Lönesummornas procentuella fördelning på kön och näringsgren 2001

\begin{tabular}{|c|c|c|c|c|c|c|}
\hline \multirow[t]{2}{*}{ Näringsgren } & \multicolumn{3}{|c|}{$\begin{array}{l}\text { Andel av inkomsttagarnas } \\
\text { lönesumma i procent }\end{array}$} & \multicolumn{3}{|c|}{$\begin{array}{l}\text { Andel av arbetspendlarnas } \\
\text { lönesumma i procent }\end{array}$} \\
\hline & Män & Kvinnor & Totalt & Män & Kvinnor & Totalt \\
\hline Jordbruk, jakt och skogsbruk & 0,4 & 0 & 0,4 & 0,4 & 0 & 0,4 \\
\hline Fiske & .. & .. & .. & .. & .. & .. \\
\hline Utvinning & .. & . & . & .. & .. & .. \\
\hline Tillverkning & 11,9 & 1,7 & 13,6 & 11,9 & 1,7 & 13,6 \\
\hline El, -gas-, värme- och vattenförsörjning & 0,3 & 0 & 0,3 & 0,3 & 0 & 0,3 \\
\hline Byggverksamhet & 2 & 0,1 & 2,1 & 1,8 & 0,1 & 1,9 \\
\hline Partihandel och detaljhandel & 11,4 & 7,2 & 18,6 & 12,6 & 8,8 & 21,3 \\
\hline Hotell- och restaurantverksamhet & 2,5 & 2 & 4,6 & 3 & 2,2 & 5,2 \\
\hline Transport, magasinering och kommunikation & 7,6 & 2 & 9,6 & 8 & 1,9 & 9,9 \\
\hline Finasiell verksamhet & 3,8 & 0,6 & 4,3 & 3,9 & 0,5 & 4,3 \\
\hline Fastighet- och uthyrningsverks, företagstj & 12,9 & 5 & 17,9 & 13 & 5,4 & 18,4 \\
\hline Offentlig förvaltning och försvar & 2,5 & 1,2 & 3,7 & 2,9 & 1,5 & 4,3 \\
\hline Utbildning & 2,3 & 1,7 & 4 & 1,5 & 1,3 & 2,8 \\
\hline Hälso- och sjukv, soc tjänster, veterinärverks & 7,4 & 6,7 & 14 & 5,7 & 5,5 & 11,3 \\
\hline Andra samhälleliga och personliga tjänster & 4,2 & 1,9 & 6,1 & 3,5 & 2,2 & 5,7 \\
\hline Förvärvsarbete i hushåll & 0 & 0 & 0 & 0 & 0 & 0 \\
\hline Verksamhet vid internat org, utländska amb & 0 & 0 & 0 & 0 & 0 & 0 \\
\hline Okänt & 0,6 & 0,1 & 0,7 & 0,5 & 0,1 & 0,6 \\
\hline Summa & 69,7 & 30,3 & 100 & 68,9 & 31,1 & 100 \\
\hline
\end{tabular}

Regional fördelning av lönesummor 
Personer boende i de tätbefolkade delarna i sydöstra Norge d.v.s. Oslo kommun, Akershus, Østfold och Vestfold fylkeskommuner svarade för 67 procent av den intjänade totala lönesumman på 341 miljoner SEK. Motsvarande andel för gränsregionerna närmast norr om detta område d.v.s. Hedmark, Sør-Trøndelag och Nord- Trøndelag fylkeskommuner var 14 procent. Övriga tolv fylkeskommuner svarade för övriga 19 procent av den totala lönesumman. En tredjedel av den totala lönesumman intjänades av personer som bodde i Oslo kommun. Ungefär hälften av denna lönesumma, 54 miljoner SEK, intjänades i Stockholms län.

Tabell 12. Lönesumman 2001 för norska löneinkomsttagare med löneinkomst i Sverige fördelade efter bostadsfylke i Norge och arbetslän i Sverige

\begin{tabular}{|c|c|c|c|c|c|}
\hline \multirow{3}{*}{$\begin{array}{l}\text { Bostadsfylke } \\
\text { Oslo }\end{array}$} & \multicolumn{2}{|c|}{ Lönesumma } & \multirow{3}{*}{$\begin{array}{l}\text { Arbetslän } \\
\text { Stockholms län }\end{array}$} & \multirow{2}{*}{\multicolumn{2}{|c|}{$\begin{array}{l}\text { Lönesumma } \\
\text { i SEK i \% }\end{array}$}} \\
\hline & \multirow{2}{*}{$\frac{\text { i SEK }}{112450493}$} & \multirow{2}{*}{$\begin{array}{l}\mathrm{i} \% \\
33,0\end{array}$} & & & \\
\hline & & & & 111847337 & 32,8 \\
\hline Akershus & 51837915 & 15,2 & $\begin{array}{l}\text { Västra Götalands } \\
\text { län }\end{array}$ & 93660028 & 27,4 \\
\hline Østfold & 51562578 & 15,1 & Värmlands län & 27405121 & 8,0 \\
\hline Hedmark & 21425123 & 6,3 & Skåne län & 12566223 & 3,7 \\
\hline Sør-Trøndelag & 13627340 & 4,0 & Jämtlands län & 12520539 & 3,7 \\
\hline Vestfold & 12937912 & 3,8 & Norrbottens län & 8849001 & 2,6 \\
\hline Hordaland & 12127582 & 3,6 & Uppsala län & 8373465 & 2,5 \\
\hline Nord-Trøndelag & 10226776 & 3,0 & Västerbottens län & 7277472 & 2,1 \\
\hline Nordland & 8966202 & 2,6 & Jönköpings län & 6861015 & 2,0 \\
\hline Buskerud & 7504229 & 2,2 & Dalarnas län & 6666099 & 2,0 \\
\hline Rogaland & 7124247 & 2,1 & Gävleborgs län & 6242949 & 1,8 \\
\hline Troms & 6531223 & 1,9 & Hallands län & 4958762 & 1,5 \\
\hline Oppland & 5765036 & 1,7 & Östergötlands län & 4723542 & 1,4 \\
\hline Telemark & 5546371 & 1,6 & Örebro län & 4397252 & 1,3 \\
\hline Møre och Romsdal & 3794878 & 1,1 & Västernorrlands län & 4228786 & 1,2 \\
\hline Sogn og Fjordane & 2779306 & 0,8 & Västmanlands län & 3582834 & 1,0 \\
\hline Vest-Agder & 2492739 & 0,7 & Okänt & 3379310 & 1,0 \\
\hline Aust-Agder & 2356659 & 0,7 & Blekinge län & 3322167 & 1,0 \\
\hline Finnmark & 2184034 & 0,6 & Kalmar län & 3221542 & 0,9 \\
\hline & & & Kronobergs län & 3161639 & 0,9 \\
\hline Summa & 341240643 & 100 & Södermanlands län & 2894908 & 0,8 \\
\hline & & & Gotlands län & 1100652 & 0,3 \\
\hline & & & Summa & 341240643 & 100 \\
\hline
\end{tabular}




\section{Rörlighet från Sverige till Norge}

Dette avsnittet beskriver arbeidskraftsstrømmene av personer med Sverige som registrert bostedsland og Norge som arbeidsstedsland. Det vil si at de har deler av eller hele sin lønnsinntekt i Norge.

I framstillingen brukes to sentrale avgrensninger. Personer med registrert lønnsinntekt i Norge og personer som er arbeidspendler over riksgrensen. Den siste gruppen er undergruppe av den første og er ut fra tidligere nevnte kriterier definert til å ha sitt hovedarbeidsforhold i Norge på det aktuelle tidspunkt.

Tabell 13. Personer bosatt i Sverige med utbetalt kontantlønn i Norge 2001. NOK

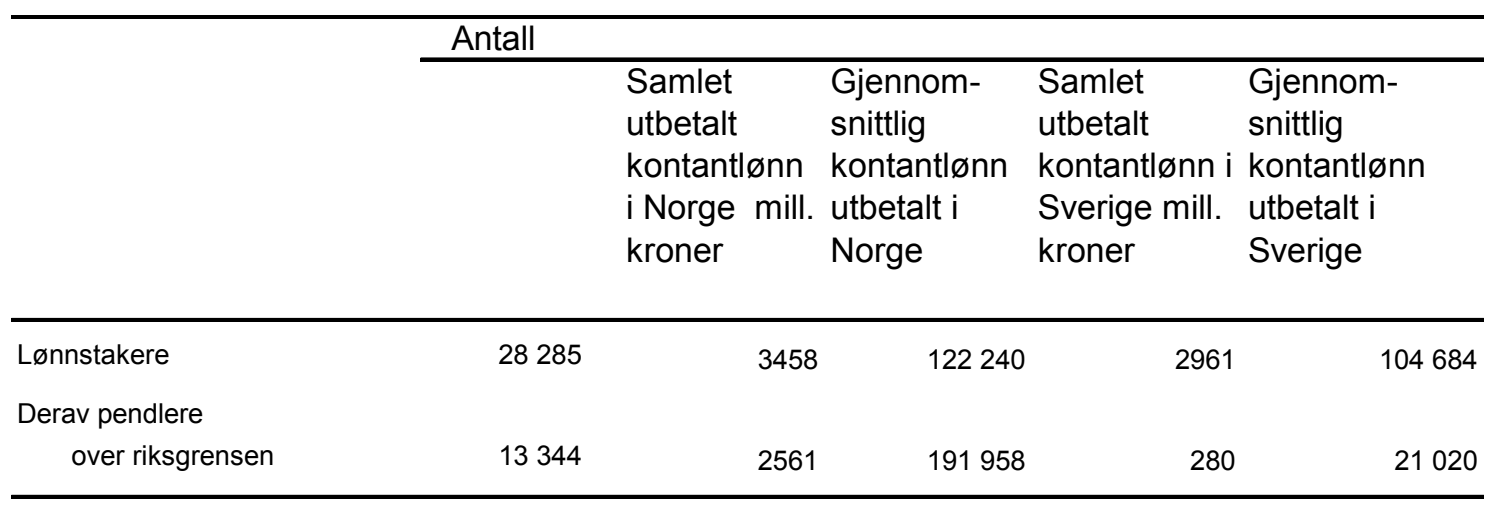

Opplysninger om lønnsutbetalinger er hentet fra Lønns- og trekkoppgaveregisteret (LTO) fra Skattedirektoratet. Kontantlønn er summen av alle kontantytelser som blir utbetalt til arbeidstakeren i løpet av et kalenderår. Størrelsen på kontantlønnen over et år vil avhenge av både lønnsatsen per time og hvor mye en person arbeidet dette året. Omfanget av arbeidet vil videre avhenge av arbeidstiden er uke og hvor mange uker personen har arbeidet. Når vi i det følgende sammenligner lønnsutbetalinger mellom ulike grupper sammenligner vi altså grupper ut fra hvor mye inntekt i form av kontantlønn de har fått utbetalt over et år. Oftest vil store forskjeller i denne størrelsen mer avspeile ulik arbeidstid enn ulik lønnsats.

Vi bruker medianlønn som begrep. Dette uttrykker en gjennomsnittlig lønnsum. Når vi fordeler alle lønnstakerne etter størrelsen på lønnsummen de har fått utbetalt, er medianlønnen lønnsummen til den personen "som ligger midt i", dvs. som har like mange personer med høyere lønn over seg som personer med lavere lønn under seg. 


\subsection{Alder}

Blant hele gruppen bosatt i Sverige med lønnsinntekt i Norge finner vi nesten dobbelt så mange menn som kvinner. De har en lavere gjennomsnittsalder enn blant lønnstakere $\mathrm{i}$ Norge generelt. Kvinnene er yngre enn mennene. Hovedvekten av mennene er mellom 25 og 44 mens kvinnene ligger mellom 20 og 34. Denne aldersforskjellen mellom kjønnene forsterker seg for gruppen som er definert som pendlere over riksgrense. Videre er det blant de som er pendlere nesten tre ganger så mange menn som kvinner.

Tabell 14. Bosatte i Sverige med lønnsinntekt i Norge etter alder og kjønn. 2001

\begin{tabular}{lrrrrrr}
\hline Alder & $\begin{array}{r}\text { Lønnetakere } \\
\text { Menn }\end{array}$ & Kvinner & Totalt & $\begin{array}{c}\text { Pendlere } \\
\text { Menn }\end{array}$ & Kvinner & Totalt \\
\hline-15 & 5 & 3 & 8 & 4 & 3 & 7 \\
$15-19$ & 548 & 539 & 1087 & 322 & 316 & 638 \\
$20-24$ & 3469 & 3044 & 6513 & 1735 & 1378 & 3113 \\
$25-34$ & 5262 & 2278 & 7540 & 2752 & 849 & 3601 \\
$35-44$ & 4210 & 1587 & 5797 & 2257 & 394 & 2651 \\
$45-54$ & 3326 & 1631 & 4957 & 1768 & 381 & 2149 \\
$55-64$ & 1520 & 573 & 2093 & 871 & 177 & 1048 \\
$65-66$ & 89 & 33 & 122 & 43 & 14 & 57 \\
$67+$ & 122 & 46 & 168 & 63 & 16 & 79 \\
Alle & 18551 & 9734 & 28285 & 9815 & 3528 & 13343 \\
\hline
\end{tabular}

Medianlønn for alle lønnstakerne er 71376 NOK. Menn i slutten av 50-årene har mest utbetalt, mens de kvinnene med mest utbetalt er litt yngre. Blant de som er definert som pendlere over riksgrensen er medianlønnen betydelig større. De har en medianlønn som er over dobbelt så stor som den for alle bosatte i Sverige med lønnsinntekt i Norge. Det har trolig sammenheng med at de i større grad er i fullt arbeid i Norge.

Tabell 15. Medianlønn for lønnstakere og pendlere etter alder 2001. NOK

\begin{tabular}{|c|c|c|c|c|c|c|}
\hline Alder & \multicolumn{3}{|c|}{$\begin{array}{l}\text { Medianlønn } \\
\text { Lønnetakere }\end{array}$} & \multicolumn{3}{|c|}{ Pendlere } \\
\hline $15-19$ & 25792 & 31038 & 28797 & 40556 & 39963 & 40511 \\
\hline $20-24$ & 60889 & 45438 & 52775 & 103078 & 74575 & 86805 \\
\hline $25-34$ & 95706 & 49657 & 78278 & 195205 & 128991 & 177687 \\
\hline $35-44$ & 122622 & 45483 & 92441 & 236934 & 187590 & 230550 \\
\hline $45-54$ & 135484 & 55613 & 100749 & 259398 & 215946 & 249822 \\
\hline $55-59$ & 153342 & 53181 & 116332 & 262718 & 195906 & 250683 \\
\hline $60+$ & 81900 & 37964 & 65252 & 186980 & 128031 & 167236 \\
\hline Alle & 92577 & 45847 & 71376 & 196617 & 96513 & 166448 \\
\hline
\end{tabular}




\subsection{Utdanning}

Langt de fleste av de bosatte i Sverige med lønnsinntekt i Norge hadde videregående eller høyere utdanning. Den klart største gruppen av mennene hadde videregående som høyeste utdanning, mens nesten halvparten av kvinnene hadde høyere utdanning. En betydelig større andel av kvinnene enn av mennene hadde høyere utdanning. Grupperer vi alle etter utdanningsnivå er det størst forskjell mellom kjønnene blant de med ingen videregående utdanning. Der er mennene klart overrepresentert.

Tabell 16. Antall lønnstakere og pendlere etter utdanningsnivå 2001.

\begin{tabular}{lrrrrrr}
\hline Utdanningsnivå & \multicolumn{2}{c}{ Lønnetakere } & \multicolumn{3}{c}{ Pendlere } \\
& Menn & Kvinner & Totalt & Menn & Kvinner & Totalt \\
\hline 1 & 2511 & 604 & 3115 & 1506 & 313 & 1819 \\
2 & 10506 & 4098 & 14604 & 6160 & 1836 & 7996 \\
3 & 4651 & 4576 & 9227 & 1592 & 1139 & 2731 \\
9 & 883 & 456 & 1339 & 557 & 240 & 797 \\
Alle & 18551 & 9734 & 28285 & 9815 & 3528 & 13343 \\
\hline
\end{tabular}

Ser vi kun på gruppen pendlere over riksgrensen er den største forskjellen at kvinnene her har jamt over lavere utdanning. Ellers er fordelingen noen lunde lik.

Medianlønnen var blant alle lønnstakerene klart høyest for de som hadde videregående som høyeste fullførte utdanning. Lavest var den for de med utdanning utover videregående. Medianlønnen for menn er dobbelt så høy som den for kvinner.

Dette mønsteret i fordeling på utdanningsnivå går ikke igjen blant pendlerne over riksgrensen. Her er det de med høyest utdanning som har mest lønn utbetalt og de med lavest utdanning som tjener minst. Forskjellen mellom kjønnene er omtrent den samme.

Tabell 17. Medianlønn for lønnstakere og pendlere etter utdanningsnivå 2001. NOK

\begin{tabular}{|c|c|c|c|c|c|c|}
\hline \multirow[t]{2}{*}{ Utdanningsnivå } & \multicolumn{3}{|c|}{$\begin{array}{l}\text { Medianlønn } \\
\text { Lønnetakere }\end{array}$} & \multicolumn{3}{|c|}{ Pendlere } \\
\hline & Menn & Kvinner & Totalt & Menn & Kvinner & Totalt \\
\hline 1 & 88050 & 37890 & 72841 & 181921 & 71628 & 160186 \\
\hline 2 & 104016 & 51481 & 81583 & 193331 & 86823 & 163494 \\
\hline 3 & 74444 & 43646 & 55722 & 249152 & 152383 & 193666 \\
\hline 9 & 80609 & 36727 & 56810 & 174164 & 62019 & 131808 \\
\hline Alle & 92577 & 45847 & 71376 & 196617 & 96513 & 166448 \\
\hline
\end{tabular}




\section{$4.3 \quad$ Næring}

Som nevnt i forrige kapittel fremstilles næringsfordelingen etter den internasjonale standarden NACE. I de norske tabellene har vi valgt å skille ut utvinning av råolje og naturgass som et eget punkt da denne næringen er spesielt interessant $i$ det norske arbeidslivet.

Tabell 18. Antall lønnstakere og pendlere etter næring 2001.

\begin{tabular}{|c|c|c|c|c|c|c|}
\hline \multirow[t]{2}{*}{ Næring } & \multicolumn{3}{|l|}{ Lønnetakere } & \multicolumn{3}{|c|}{ Pendlere } \\
\hline & Menn & Kvinner & Totalt & Menn & Kvinner & Totalt \\
\hline 01-05 Jorbruk, skogbruk og fiske & 240 & 89 & 329 & 123 & 34 & 157 \\
\hline 10,12-37 Industri og bergversdrift & 2933 & 927 & 3860 & 1622 & 486 & 2108 \\
\hline 11 Utvinning av råolje og naturgass & 224 & 18 & 242 & 188 & 13 & 201 \\
\hline 40-41,90 Kraft-og vannforsyning, avfall & 33 & 9 & 42 & 16 & .. & 18 \\
\hline 45 Bygge- og anleggsvirksomhet & 5856 & 49 & 5905 & 3704 & 17 & 3721 \\
\hline 50-64 Varehandel, hotell- og restaurant, transport og kommunikasjon & 3573 & 2506 & 6079 & 2008 & 1158 & 3166 \\
\hline 65-74 Finansell- og forretningstjenesteyting, eiendomsdrift & 2323 & 1359 & 3682 & 1157 & 537 & 1694 \\
\hline 75 Offentlig adminstrasjon,forsvar,trygdeordning & 1409 & 1932 & 3341 & 313 & 355 & 668 \\
\hline 80 Undervisning & 234 & 150 & 384 & 98 & 74 & 172 \\
\hline 85 Helse- og sosialtjenester & 1071 & 2247 & 3318 & 306 & 664 & 970 \\
\hline 92 Kulturell og annen personlig tjenesteyting, sport & 301 & 240 & 541 & 135 & 98 & 233 \\
\hline 91 Interesseorganisasjoner & 45 & 58 & 103 & 22 & 26 & 48 \\
\hline 95 Lønnet arbeid i private husholdninger & .. & 23 & 25 & .. & .. & .. \\
\hline Uoppgitt & 307 & 127 & 434 & 122 & 62 & 184 \\
\hline I alt & 18551 & 9734 & 28285 & 9815 & 3528 & 13343 \\
\hline
\end{tabular}

Den største forekomsten av lønnstakere registrert bosatt i Sverige var det i næringene varehandel, hotell- og restaurant, transport og kommunikasjon og innen bygg- og anleggvirksomhet. Flest menn jobbet i Bygg- og anlegg. Her er det nesten ingen kvinner. Kvinnene derimot er i klart flertal innen helse- og sosiale tjenester.

Menn som er definert som pendlere er i enda større grad konsentrert om næringene bygg- og anlegg. Kvinnene som pendler er mer konsentrert om varehandel, hotell- og restaurant, transport og kommunikasjon og jobber i betydelig mindre grad i helse- og sosial.

Tabell 19. Medianlønn etter næringsgren 2001. 


\begin{tabular}{|c|c|c|c|c|c|c|}
\hline \multirow[t]{2}{*}{ Naring } & \multirow{2}{*}{$\begin{array}{c}\text { Medianlønn } \\
\text { Lønnetakere } \\
\text { Menn }\end{array}$} & \multicolumn{5}{|c|}{ Pendlere } \\
\hline & & Kvinner & Totalt & Menn & Kvinner & Totalt \\
\hline 01-05 Jorbruk, skogbruk og fiske & 42236 & 21840 & 33720 & 117176 & 34621 & 99312 \\
\hline $10,12-37$ Industri og bergversdrift & 83067 & 57510 & 73897 & 178889 & 75593 & 140955 \\
\hline 11 Utvinning av råolje og naturgass & 472336 & 418517 & 470825 & 523516 & 569394 & 525273 \\
\hline 40-41,90 Kraft-og vannforsyning, avfall & 88850 & 75000 & 82967 & 249097 & 459405 & 262525 \\
\hline 45 Bygge- og anleggsvirksomhet & 136715 & 43777 & 135525 & 220491 & 99773 & 220317 \\
\hline 50-64 Varehandel, hotell- og restaurant, transport og kommunikasjon & 87058 & 51101 & 67658 & 174213 & 82839 & 130113 \\
\hline 65-74 Finansell- og forretningstjenesteyting, eiendomsdrift & 76214 & 40779 & 59727 & 150027 & 101630 & 134019 \\
\hline 75 Offentlig adminstrasjon,forsvar,trygdeordning & 38524 & 25054 & 29662 & 118248 & 91248 & 98226 \\
\hline 80 Undervisning & 113865 & 109836 & 112163 & 279102 & 199122 & 240270 \\
\hline 85 Helse- og sosialtjenester & 91621 & 66943 & 72970 & 263210 & 178995 & 201455 \\
\hline 92 Kulturell og annen personlig tjenesteyting, sport & 55439 & 39914 & 47309 & 140145 & 67243 & 108352 \\
\hline 91 Interesseorganisasjoner & 30132 & 38070 & 36372 & 88507 & 53822 & 66375 \\
\hline 95 Lonnet arbeid i private husholdninger & 19472 & 29451 & 26451 & 3671 & 30097 & 26451 \\
\hline Uoppgitt & 46237 & 35415 & 40626 & 140390 & 53136 & 116997 \\
\hline I alt & 92577 & 45847 & 71376 & 196617 & 96513 & 116448 \\
\hline
\end{tabular}

Medianlønn for hele gruppen var klart høyest i oljenæringen. Dette gjaldt både for menn og kvinner. Uten om denne næringen henter mennene mest lønn ut innen bygg- og anlegg og kvinnene mest innen undervisning. Innen de store næringene talt $i$ antall lønnstakere er det interessant å se at medianlønnen i bygg- og anlegg var dobbelt så stor som i varehandel, hotell- og restaurant, transport og kommunikasjon.

Blant pendlerne blir den høye utbetalte kontantlønnen i oljenæringen enda mer markert. I oljenæringen er medianlønnen for kvinner i tillegg høyere enn den for menn.

\subsection{Sektor}

Dette avsnittet beskriver fordelingen av arbeid utført i offentlige forvaltning og i det private næringslivet. Offentlig eide foretak er inkludert i den sistnevnte kategorien. Telenor og Posten er eksempler på offentlig eide foretak.

Kun omkring 20 prosent av lønnstakerene bosatt i Sverige med lønnsinntekt i Norge er knyttet til offentlig forvaltning. Kvinner er i større grad enn menn i det offentlige.

Blant pendlerne over riksgrensen er andelen i det offentlige redusert til 10 prosent.

Tabell 20. Antall lønnstakere og pendlere etter sektor 2001.

\begin{tabular}{lrrrrrr}
\hline Sektor & \multicolumn{2}{c}{ Lønnetakere } & \multicolumn{3}{c}{ Pendlere } \\
& Menn & Kvinner & Totalt & Menn & Kvinner & Totalt \\
\hline & 2363 & 3757 & 6120 & 586 & 831 & 1417 \\
Offentlig forvaltning & 15850 & 5884 & 21734 & 9077 & 2657 & 11734 \\
Næringslivet inkludert offentlig eide foretak & 338 & 93 & 431 & 152 & 40 & 192 \\
Uoppgitt & 18551 & 9734 & 28285 & 9815 & 3528 & 13343 \\
Alle & & & & &
\end{tabular}


Personer som er registrert bosatt i Sverige og har lønnsinntekt i Norge hadde en høyere medianlønn i næringslivet enn innen offentlig forvaltning. Dette gjelder både menn og kvinner.

Blant både menn og kvinner som er definert som pendlere derimot er medianlønnen høyere innen offentlig forvaltning enn i næringslivet. Forskjellen er størst for kvinner. De tjente nesten dobbelt så mye i det offentlige.

Tabell 21. Medianlønn for lønnstakere og pendlere etter sektor 2001. NOK

\begin{tabular}{|c|c|c|c|c|c|c|}
\hline \multirow[t]{2}{*}{ Sektor } & \multicolumn{3}{|c|}{$\begin{array}{l}\text { Medianlønn } \\
\text { Lønnetakere }\end{array}$} & \multicolumn{3}{|l|}{ Pendlere } \\
\hline & Menn & Kvinner & Totalt & Menn & Kvinner & Totalt \\
\hline Offentlig forvaltning & 58967 & 41367 & 47727 & 207765 & 160472 & 176316 \\
\hline Næringslivet inkludert offentlig eide foretak & 101238 & 49921 & 80075 & 195846 & 86290 & 165625 \\
\hline Uoppgitt & 60122 & 28630 & 40683 & 197522 & 39046 & 161013 \\
\hline Alle & 92577 & 45847 & 71367 & 196617 & 96513 & 166448 \\
\hline
\end{tabular}

\subsection{Føderegion}

Av de 28285 personene som var registrert bosatt i Sverige og hadde registrert lønnsinntekt i Norge i 2001 var hele 3631 født i Norge. Vi ser ikke på hvilke statsborgerskap personene har. Dette er en mye lavere andel "tilbakependlere" en tallet på svenskfødte som bor i Norge med lønnsinntekt i Sverige.

Den klart største gruppen er født i Sverige, og foruten de som er født i Norge og Sverige er Finland representert med flest.

Pendlerne over riksgrensen er i stor grad fordelt på samme måte som hele gruppen. Den mest markante forskjellen er at blant disse er en betydelig større andel kvinner svenskfødte. Altså er de født i Sverige, registrert bosatt i Sverige men med hovedarbeidsforhold i Norge.

Tabell 22. Lønnstakere og pendlere etter føderegion 2001.

\begin{tabular}{|c|c|c|c|c|c|c|}
\hline \multirow[t]{2}{*}{ Foderegion } & \multicolumn{3}{|c|}{ Lønnetakere } & \multicolumn{3}{|l|}{ Pendlere } \\
\hline & Menn & Kvinner & Totalt & Menn & Kvinner & Totalt \\
\hline Norge & 2175 & 1456 & 3631 & 1413 & 754 & 2167 \\
\hline Sverige & 14622 & 7603 & 22225 & 7564 & 2544 & 10108 \\
\hline Andre & 1754 & 675 & 2429 & 832 & 227 & 1059 \\
\hline Alle & 18551 & 9734 & 28285 & 9815 & 3528 & 13343 \\
\hline
\end{tabular}

Medianen av utbetalt kontantlønn er i stor grad ulik fra gruppe til gruppe når vi ser på fødeland. For hele gruppen lønnstakere er median lønnsutbetalingen størst for de født i Danmark. Nært etterfulgt av Norge. Ser vi på de kjønnsfordelte tallene for lønnstakere 
er det interessant å observere at kvinner med fødeland Sverige faktisk har utbetalt mer $\mathrm{i}$ Norge enn kvinner med fødeland Norge. For menn er tallene motsatt og med en mer markant forskjell.

Ser vi kun på gruppen pendlere over riksgrensen er det for både kvinner og menn høyere medianlønn til personer født i Norge enn personer født i Sverige. Dette kan underbygge en hypotese om at blant personer bosatt i Sverige med lønnsinntekt i Norge er arbeidsintensiteten og sannsynligheten for å jobbe fulltid større blant de som opprinnelig kommer fra Norge.

Tabell 23. Medianlønn for lønnstakere og pendlere etter føderegion 2001. NOK

\begin{tabular}{|c|c|c|c|c|c|c|}
\hline \multirow[t]{2}{*}{ Foderegion } & \multicolumn{3}{|c|}{$\begin{array}{l}\text { Medianlønn } \\
\text { Lønnetakere }\end{array}$} & \multicolumn{3}{|l|}{ Pendlere } \\
\hline & Menn & Kvinner & Totalt & Menn & Kvinner & Totalt \\
\hline Norge & 133019 & 44548 & 84498 & 231720 & 113620 & 185719 \\
\hline Sverige & 91633 & 45696 & 70542 & 195205 & 94146 & 164925 \\
\hline Andre & 77382 & 54806 & 68221 & 155909 & 107785 & 142367 \\
\hline Alle & 92577 & 45847 & 71376 & 196617 & 96513 & 166448 \\
\hline
\end{tabular}

\subsection{Regionale fordelinger}

Som nevnt i forrige kapittel er store deler av grenseområdene mellom Sverige og Norge meget tynt befolket. Befolkningstyngdepunktet er i sør med Østfold, Akershus og Hedmark på norsk side og Västra Götaland og Värmland på svensk side. Denne fordelingen er klart avspeilet $i$ arbeidskraftstrømmene over riksgrensen. En annen ting vi klart ser er at hovedstadsregionen i Norge rundt Oslo i mye større grad enn tilsvarende region rundt Stockholm er en del av det grenseoverskridende arbeidsmarkedet.

\section{Lønnstakere}

28285 personer registrert bosatt i Sverige hadde i løpet av året 2001 utbetalt kontantlønn i Norge. Neste 60 prosent av disse er bosatt i län som grenser til Norge og klart flest i Västra Götaland og Värmland. Fordelt på arbeidsstedsfylke i Norge kan gruppen grovt sett deles i tre. En tredjedel i Oslo, en tredjedel i grensefylkene mot Sverige og en i resten av landet. 
Tabell 24. Antall bosatte i Sverige med lonnsinntekt i Norge 2001 fordelt etter bostedslän.

\begin{tabular}{|c|c|c|c|}
\hline Bostedslän & $\begin{array}{l}\text { Antal } \\
\text { lønnetakere }\end{array}$ & $\begin{array}{c}\text { derav } \\
\text { pendlere }\end{array}$ & $\begin{array}{c}\text { Andel } \\
\text { pendlere }\end{array}$ \\
\hline Västra Götaland & 7705 & 3942 & 51,2 \\
\hline Värmland & 4835 & 3023 & 62,5 \\
\hline Dalarna & 1183 & 628 & 53,1 \\
\hline Jämtland & 860 & 412 & 47,9 \\
\hline Västerbotten & 780 & 350 & 44,9 \\
\hline Norrbotten & 729 & 317 & 43,5 \\
\hline Grenselän i alt & 16092 & 8672 & 53,9 \\
\hline Stockholm & 2717 & 912 & 33,6 \\
\hline$\varnothing$ vrige län & 9476 & 3759 & 39,7 \\
\hline I alt & 28285 & 13343 & 47,2 \\
\hline
\end{tabular}

\section{Pendlere over riksgrensen}

Av de 13343 personene klasifisert som pendlere over riksgrensen bodde rundt 65 prosent i län langs grensen, sju prosent bodde i Stockholm og 28 prosent i resten av Sverige. Som en andel av alle med lønnsinntekt i Norge var Värmland det länet med størst andel pendlere.

Av pendlerene arbeidet 36 prosent i Oslo. Litt flere var sysselsatt i grensefylkene og en del færre i resten av Norge. Som en andel av alle med lønnsinntekt i Norge var Oslo det fylket med størst andel pendlere med 53 prosent, men grensefylkene Østfold, Akershus og Hedmark fulge ikke langt etter. 
Tabell 25. Antall bosatte i Sverige med lønnsinntekt i Norge 2001 fordelt etter arbeidsfylke.

\begin{tabular}{|c|c|c|c|}
\hline \multirow[t]{2}{*}{ Arbeidsfylke } & \multirow[b]{2}{*}{$\begin{array}{l}\text { Antal } \\
\text { lønnetakere }\end{array}$} & \multirow[b]{2}{*}{$\begin{array}{c}\text { derav } \\
\text { pendlere }\end{array}$} & \multirow[b]{2}{*}{$\begin{array}{c}\text { Andel } \\
\text { pendlere }\end{array}$} \\
\hline & & & \\
\hline Østfold & 2791 & 1463 & 52,4 \\
\hline Akershus & 3307 & 1646 & 49,8 \\
\hline Hedmark & 1372 & 658 & 48 \\
\hline Sør-Trøndelag & 881 & 348 & 39,5 \\
\hline Nord-Trøndelag & 262 & 111 & 42,4 \\
\hline Nordland & 1002 & 311 & 31 \\
\hline Troms & 773 & 263 & 34 \\
\hline Finnmark & 452 & 117 & 25,9 \\
\hline Grensefylker i alt & 10840 & 4917 & 45,4 \\
\hline Oslo & 8985 & 4763 & 53 \\
\hline Øvrige fylker & 8460 & 3663 & 43,3 \\
\hline I alt & 28285 & 13343 & 47,2 \\
\hline
\end{tabular}

\section{Grenseregioner}

Tabellen under viser fordelingen av lønnstakere og pendlere over de grenseoverskridende sammarbeidsregionene nærmere beskrevet i forrige kapittel.

Den største arbeidskraftsstrømmen fra Sverige til Norge innen samme region finner vi i Indre Skandinavia. Dette er et område med relativt stor geografisk utsterkning.

Den høyeste andelen pendlere derimot finner vi i området Grenseløst sammarbeide. Dette er det sørligste området der også avstandene er kortest. Blant de som bor i en grensekommune i Sverige i dette området og arbeider i en grensekommune på norsk side i samme område er hele 77,6 prosent definert som pendlere. Det vil si at de har sitt hovedarbeidsforhold i Norge. 
Tabell 26. Antall bosatte i svensk grenseregion med lønnsinntekt i motsvarende norsk grenseregion 2001.

\begin{tabular}{lccc}
\hline Grenseregion & $\begin{array}{c}\text { Antal } \\
\text { lønnetakere }\end{array}$ & $\begin{array}{c}\text { derav } \\
\text { pendlere }\end{array}$ & $\begin{array}{c}\text { Andel } \\
\text { pendlere } \\
\text { i \% av } \\
\text { lønnetakere }\end{array}$ \\
\hline Grenseløst samarbeidet & 842 & 577 & 68,5 \\
derav lønnsinntekt i grensekommune & 295 & 229 & 77,6 \\
Indre Skandinavia & 1427 & 949 & 66,5 \\
derav lønnsinntekt i grensekommune & 799 & 553 & 69,2 \\
Nordens grønne belte & 316 & 161 & 50,9 \\
derav lønnsinntekt i grensekommune & 94 & 56 & 59,6 \\
Grenseregionene samlet & 2585 & 1687 & 65,3 \\
derav lønnsinntekt i grensekommune & 1188 & 839 & 70,5 \\
\hline
\end{tabular}

\subsection{Lønnssummer}

Blant personene bosatt i Sverige med kontantlønn utbetalt i Norge i løpet av 2001 hadde 41 prosent en høyere kontantlønn utbetalt i hjemmlandet. Altså har et flertall større inntekt fra arbeid i Norge.

Figuren under viser summen av lønnstakerenes kontantlønn fordelt på desiler av lønnstakere. De 10 prosentene av lønnstakerne som hadde mest utbetalt i Norge hadde tilsammen utbetalt over 1,2 miliarder kroner i Norge mens de hadde i underkant av 150 milioner utbetalt i Sverige. I de fire øverste desilene er sum av utbetalt kontantlønn størst i Norge. Dette gjennspeiles i at vi har definert nesten halvparten av individene som pendlere over riksgrense og med sitt hovedarbeidsforhold i Norge. 
Diagram 2. Lønnsummer fordelt etter desiler av lønnstakere. 2001.

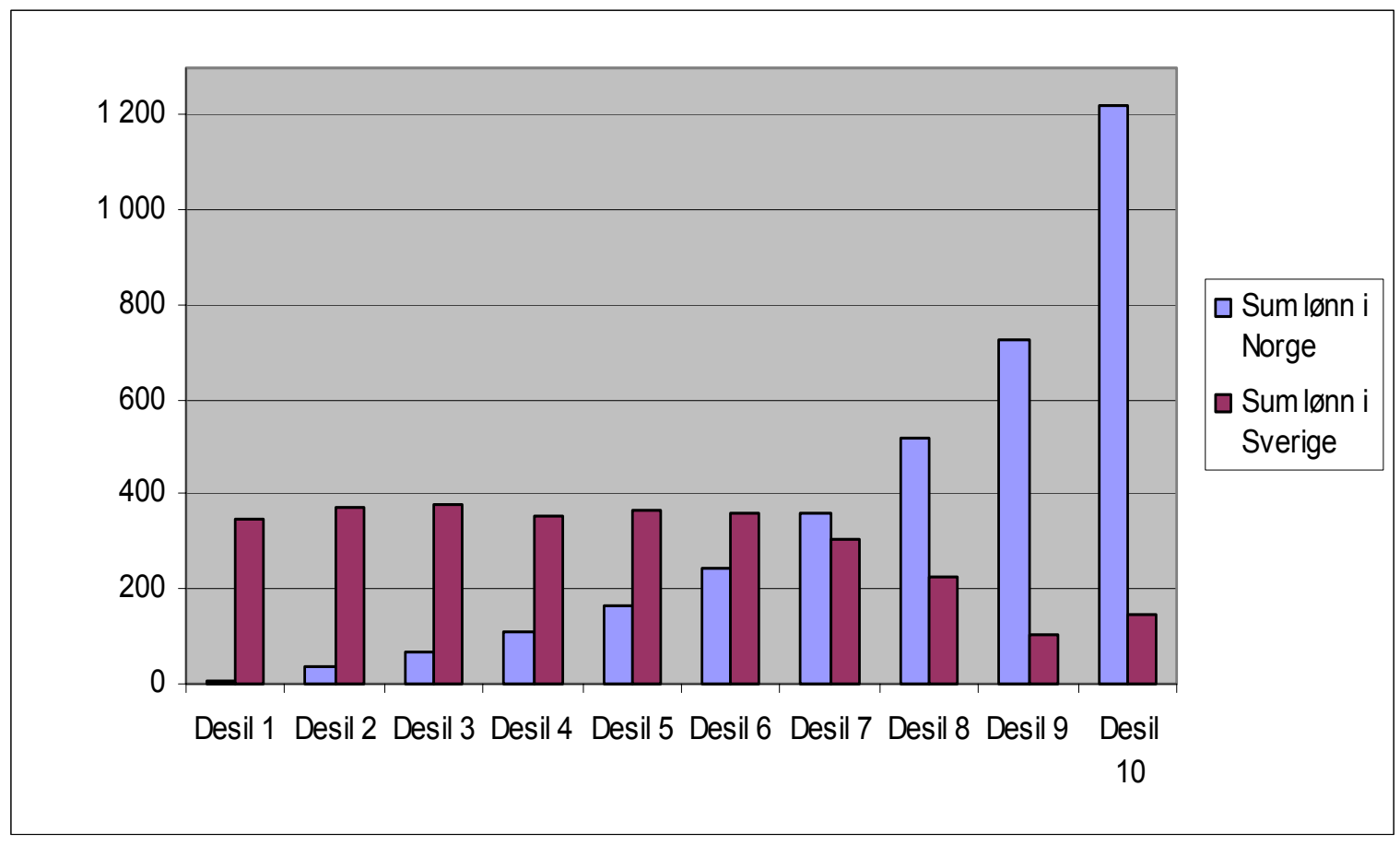

\section{Næring}

Personer registrert bosatt i Sverige fikk utbetalt som kontantlønn tilsammen 3, 4 milliarder kroner i løpet av 2001 i følge lønns og trekkoppgaveregisteret. De av disse som ble definert som pendlere over riksgrense hadde til sammenligning utbetalt 2,5 milliarder.

Tabell 27. Lønnsummer fordelt på kjønn og næring. NOK. 2001.

\begin{tabular}{|c|c|c|c|c|c|c|}
\hline \multirow[t]{2}{*}{ Næring } & \multirow{2}{*}{$\begin{array}{r}\text { Lønnetakere } \\
\text { Menn }\end{array}$} & \multicolumn{5}{|c|}{ Pendlere } \\
\hline & & Kvinner & Totalt & Menn & Kvinner & Totalt \\
\hline 01-05 Jorbruk, skogbruk og fiske & 21053410 & 3396675 & 24450085 & 16451392 & 1960927 & 18412319 \\
\hline $10,12-37$ Industri og bergversdrift & 415272499 & 71762793 & 487035292 & 326356850 & 50503529 & 376860379 \\
\hline 11 Utvinning av råolje og naturgass & 98877394 & 7479310 & 106356704 & 94709571 & 6500586 & 101210157 \\
\hline 40-41,90 Kraft-og vannforsyning, avfall & 4788761 & 1408049 & 6196810 & 4020775 & 918811 & 4939586 \\
\hline 45 Bygge- og anleggsvirksomhet & 917987869 & 4781297 & 922769166 & 790553271 & 2979128 & 793532395 \\
\hline 50-64 Varehandel, hotell- og restaurant, transport og kommunikasjon & 498128781 & 190497021 & 688625802 & 399782092 & 124589543 & 524371635 \\
\hline 65-74 Finansell- og forretningstjenesteyting, eiendomsdrift & 323607106 & 109326213 & 432933319 & 234125991 & 72260552 & 306386543 \\
\hline 75 Offentlig adminstrasjon,forsvar,trygdeordning & 113007235 & 101152853 & 214160088 & 53162450 & 44090925 & 97253375 \\
\hline 80 Undervisning & 39805329 & 21518884 & 61324213 & 26223909 & 15744372 & 41968281 \\
\hline 85 Helse- og sosialtjenester & 178676294 & 234068150 & 412744444 & 99585849 & 125807489 & 225393338 \\
\hline 92 Kulturell og annen personlig tjenesteyting, sport & 35852646 & 17284680 & 53137326 & 28371473 & 10218220 & 38589693 \\
\hline 91 Interesseorganisasjoner & 3493675 & 4462570 & 7956245 & 2720315 & 2789286 & 5509601 \\
\hline 95 Lonnet arbeid i private husholdninger & 38945 & 589230 & 628175 & 3671 & 60196 & 63867 \\
\hline Uoppgitt & 28719941 & 10525186 & 39245127 & 18838592 & 7967550 & 26806142 \\
\hline I alt & 2679309885 & 778252911 & 3457562796 & 2094906201 & 466391114 & 2561297315 \\
\hline
\end{tabular}

Fordelingen av lønnsummene på næring viser at den klart største næringen er bygge- og anleggvirksomhet etterfulgt av varehandel, hotell og restaurant, transport og kommunikasjon. Forskjellen på næringsfordeling mellom kjønnene er meget stor. 
Særlig innen bygg og anlegg. Den klart største lønnsummen for kvinner er innen helseog sosiale tjenester.

Tabell 28. Lønnsummer fordelt på kjønn og næring. Prosent. 2001.

\begin{tabular}{|c|c|c|c|c|c|c|}
\hline \multirow[t]{2}{*}{ Næring } & \multicolumn{2}{|l|}{ Lønnetakere } & \multicolumn{3}{|c|}{ Pendlere } & \multirow[b]{2}{*}{ Totalt } \\
\hline & Menn & Kvinner & Totalt & Menn & Kvinner & \\
\hline 01-05 Jorbruk, skogbruk og fiske & 1 & 0 & 1 & 1 & 0 & 1 \\
\hline $10,12-37$ Industri og bergversdrift & 15 & 9 & 14 & 16 & 11 & 15 \\
\hline 11 Utvinning av råolje og naturgass & 4 & 1 & 3 & 5 & 1 & 4 \\
\hline 40-41,90 Kraft-og vannforsyning, avfall & 0 & 0 & 0 & 0 & 0 & 0 \\
\hline 45 Bygge- og anleggsvirksomhet & 34 & 1 & 27 & 38 & 1 & 31 \\
\hline 50-64 Varehandel, hotell- og restaurant, transport og kommunikasjon & 19 & 24 & 20 & 19 & 27 & 20 \\
\hline 65-74 Finansell- og forretningstjenesteyting, eiendomsdrift & 12 & 14 & 13 & 11 & 15 & 12 \\
\hline 75 Offentlig adminstrasjon,forsvar,trygdeordning & 4 & 13 & 6 & 3 & 9 & 4 \\
\hline 80 Undervisning & 1 & 3 & 2 & 1 & 3 & 2 \\
\hline 85 Helse- og sosialtjenester & 7 & 30 & 12 & 5 & 27 & 9 \\
\hline 92 Kulturell og annen personlig tjenesteyting, sport & 1 & 2 & 2 & 1 & 2 & 2 \\
\hline 91 Interesseorganisasjoner & 0 & 1 & 0 & 0 & 1 & 0 \\
\hline 95 Lønnet arbeid i private husholdninger & 0 & 0 & 0 & 0 & 0 & 0 \\
\hline Uoppgitt & 1 & 1 & 1 & 1 & 2 & 1 \\
\hline I alt & 77 & 23 & 100 & 82 & 18 & 100 \\
\hline
\end{tabular}

\section{Regional fordeling av lonnsummer}

Halvparten av den registrerte utbetalt kontantlønnen i Norge til personer registrert bosatt i Sverige er utbetalt til personer registrert bosatt i Västra Götaland eller Värmland. Dette området har til sammenligning i underkant av 20 prosent av Sveriges befolkning.

Nesten 60 prosent kontantlønnen hentes i Oslo, Akershus og Østfold. Ellers er det relativt jevnt fordelt utover landet. Det bør også nevnes at en betydelig lønnsum også kommer fra utenfor fastlandsnorge på kontinentalsokkelen. 
Tabell 29. Lønnsummer fordelt etter bostedslän i Sverige og arbeidsfylke i Norge. NOK og prosent. 2001.

\begin{tabular}{|c|c|c|c|c|c|}
\hline Bostedslän & Lønnsum & i $\%$ & Arbeidsfylke & $\begin{array}{l}\text { Lønnsum } \\
\text { iNOK }\end{array}$ & j \% \\
\hline & & $\mathrm{i} \%$ & & & $1 \%$ \\
\hline Stockholm & 342456031 & 9,9 & Østfold & 385796297 & 11,2 \\
\hline Uppsala & 59147346 & 1,7 & Akershus & 430570811 & 12,5 \\
\hline Södermanland & 41152453 & 1,2 & Oslo & 1203280759 & 34,8 \\
\hline Östergötland & 78903634 & 2,3 & Hedemark & 169791418 & 4,9 \\
\hline Jönköping & 39245070 & 1,1 & Oppland & 48340240 & 1,4 \\
\hline Kronoberg & 22605569 & 0,7 & Buskerud & 133226956 & 3,9 \\
\hline Kalmar & 49537986 & 1,4 & Vestfold & 156087724 & 4,5 \\
\hline Gotland & 13589117 & 0,4 & Telemark & 52764241 & 1,5 \\
\hline Blekinge & 34321484 & 1,0 & Aust-Agder & 23603763 & 0,7 \\
\hline Skåne & 227812994 & 6,6 & Vest-Agder & 20710649 & 0,6 \\
\hline Hallands & 107913610 & 3,1 & Rogaland & 97518877 & 2,8 \\
\hline Västra Götaland & 1067853930 & 30,9 & Hordaland & 115349970 & 3,3 \\
\hline Värmland & 707344996 & 20,5 & Sogn og Fjordane & 47431911 & 1,4 \\
\hline Örebro & 88454932 & 2,6 & Møre og Romsdal & 83054497 & 2,4 \\
\hline Västmanland & 47583677 & 1,4 & Sør-Trøndelag & 86213650 & 2,5 \\
\hline Dalarna & 152671721 & 4,4 & Nord-Trøndelag & 23608562 & 0,7 \\
\hline Gävleborg & 78359292 & 2,3 & Nordland & 93000849 & 2,7 \\
\hline Västermorrland & 64869624 & 1,9 & Troms & 75903667 & 2,2 \\
\hline Jämtland & 91692861 & 2,7 & Finnmark & 40922183 & 1,2 \\
\hline Västerbotten & 68714446 & 2,0 & Svalbard & 7198256 & 0,2 \\
\hline \multirow[t]{2}{*}{ Norrbotten } & 73332022 & 2,1 & Kontinentalsokkelen & 157441525 & 4,6 \\
\hline & & & Uoppgitt & 5745992 & 0,2 \\
\hline I alt & 3457562794 & 100 & & 3457562797 & 100 \\
\hline
\end{tabular}




\section{Att studera ytterligare}

\section{Utveckling över tiden:}

Den redovisning som ingår i projektet Nordisk pendlingskarta avser förhållanden under år 2001. Därför ger resultaten endast en uppfattning av nivåerna på deföreteelser som redovisas. Med uppgifter från flera år är det möjligt att följa vad arbetsmarknadskonjunkturer betyder, gränshinders betydelse o.s.v.

\section{Redovisning på karta}

Andel av förvärvsarbetande per kommun som arbetat i Norge ??

Varifrån kom de som hade löneinkomst i Norge, antalsmässigt

Andelar av dem som hade löneinkomst i Norge??

\section{Arbetspendlare över riksgräns}

Vad har gränspendlarna för sysselsättningsstatus i befintlig sysselsättningsstatistik,

\section{Flyttare}

Hur många ar arbetspendlare över riksgräns hade flyttat året före / året efter?

Flyttar man till arbete i samma bransch eller byter man bransch med flyttningen?

Flyttar man från arbetslöshet till sysselsättning ..? 


\section{Bilaga 1. Metodbeskrivning}

I Sverige, Norge, Danmark och Finland finns en registerbaserad sysselsättningsstatistik som är likartat uppbyggd och kan användas för att beskriva integrationen på den nordiska arbetsmarknaden. Metoden utgår från personer som finns registrerade med inkomst i arbetslandet men som saknas i centrala personregister. Dessa personer har anställning i arbetslandet och är inte folkbokförda i landet i fråga. Genom att utbyta uppgifter om dessa personer mellan två länder är det möjligt att identifiera personernas bostadsland. Resultatet blir en grupp människor som bor i ett land och har löneinkomst $\mathrm{i}$ ett annat. Från denna grupp kan man därefter utifrån särskilda kriterier avskilja personer som betraktas som arbetspendlare över riksgräns.

Det finns flera syften med att belysa antalet personer som arbetar i ett land och bor i ett annat:

- Mått på integrationen mellan länderna

- Rörligheten på nordisk arbetsmarknad

- Flödet av arbetsinkomster mellan länderna

- Förbättra den nationella sysselsättningsstatistiken. De personer som arbetar i ett land och bor i ett annat kommer inte med i arbetslandets statistik och redovisas som ej förvärvsarbetande i bostadslandets statistik.

- Fördjupa jämförelserna mellan de nordiska ländernas arbetsmarknader (benchmarking)

\section{Personnummer och matchning}

De nordiska länderna har väl utbyggda administrativa system för bl.a. folkbokföring och taxering. I dessa system identifieras personer med unika personnummer. Numren är olika konstruerade i de olika länderna, varför det inte utan vidare går att matcha på personnummer mellan ländernas register. Däremot finns uppgifter om födelsedatum, kön och namn registrerade i registren. Genom att kombinera dessa uppgifter är det möjligt att göra jämförelser mellan de uppgifter som finns om de aktuella personerna $\mathrm{i}$ båda ländernas register. Då namnregistrering kan ske på olika sätt i respektive land, t.ex. genom annorlunda stavning eller olika antal förnamn, är systemet inte helt vattentätt. Även efter manuella genomgångar där namnuppsättningar jämförs kan det hända att ett fătal personer inte betraktas som matchande och därför inte kommer med i statistiken fast de borde ha räknats med. 
Tabell 1. Namnmatchning för att identifiera svenska inkomsttagare i Norge

\begin{tabular}{|c|c|c|c|c|}
\hline Kod & Maskinell bearbetning & $\begin{array}{l}\text { God- } \\
\text { kända }\end{array}$ & $\begin{array}{l}\text { Ej god- } \\
\text { kända }\end{array}$ & Totalt \\
\hline 1 & Efternamn, mellannamn och förnamn är identiska från början & 22724 & & \\
\hline 2 & $\begin{array}{l}\text { Norska bokstäver, } \varnothing \text { och } Æ \text {, omgjorda till svenska } \\
\text { bokstäver i något av namnen, sedan identiska }\end{array}$ & 1878 & & \\
\hline 3 & $\begin{array}{l}\text { Efternamn och förnamn är identiska från början bortsett från att } \\
\text { mellannamn saknas i ena fallet }\end{array}$ & 77 & & \\
\hline \multirow[t]{3}{*}{4} & $\begin{array}{l}\text { Norska bokstäver, } \varnothing \text { och } Æ \text {, i efternamn och/eller förnamn omgjorda } \\
\text { till svenska bokstäver sedan identiskt bortsett från att mellannamn } \\
\text { saknas i ena fallet }\end{array}$ & 3 & & \\
\hline & Summa & 24682 & 0 & 24682 \\
\hline & Manuell granskning efter maskinell bearbetning & & & \\
\hline 5 & $\begin{array}{l}\text { Samma efternamn och mellannamn, men fler förnamn } \\
\text { i norska eller svenska materialet, förnamnen måste i något fall } \\
\text { likna varandra för att vi skall betrakta det som matchning }\end{array}$ & 2752 & 87 & 2839 \\
\hline 6 & Samma som ovan efter omgjorda norska bokstäver i någon del & 246 & 1 & 247 \\
\hline 7 & Samma efternamn olika mellan- och förnamn, se 5 om likhet & 351 & 2 & 353 \\
\hline 8 & $\begin{array}{l}\text { Samma som ovan när norska bokstäver ändrats } \\
\text { För kod 5-8 krävs dessutom att någon del i förnamnet skall } \\
\text { likna förnamnet i det jämförda materialet }\end{array}$ & 20 & & 20 \\
\hline 9 & Samma förnamn och mellannamn & 56 & 1 & 57 \\
\hline 10 & $\begin{array}{l}\text { Samma förnamn och mellannamn när någon del innehåller } \\
\text { omgjorda norska bokstäver }\end{array}$ & $\begin{array}{l}0 \\
1\end{array}$ & & \\
\hline 11 & Samma förnamn & 241 & & 241 \\
\hline 12 & $\begin{array}{l}\text { Samma förnamn efter omgjorda norska bokstäver } \\
\text { För kod 9-12 krävs dessutom att någon del i efternamnet skall } \\
\text { likna efternamnet } i \text { det jämförda materialet }\end{array}$ & 1 & & 1 \\
\hline & Summa & 3668 & 91 & 3759 \\
\hline & Totalt & 28350 & 91 & 28441 \\
\hline
\end{tabular}

\section{Sekretess}

Utlämnandeprövning ur sekretessynpunkt har skett vid respektive statistikmyndighet eller av därför särskilt utsedd funktion i landet. Vid denna prövning har värdet av att få en statistisk bild av arbetsflöden mellan de nordiska länderna och att åstadkomma en förbättrad statistik i respektive land vägts mot det faktum att materialet överlämnas till en annan nordisk statistikmyndighet. I samtliga fall har tillstånd givits för utlämning av material utom ett fall. Den finska lagstiftningen tillåter inte utlämnande av uppgifter om enskilda personer till annat land, vilket har resulterat i att en särskild lösning har fått tillämpas i kontakterna med Finland. Resultaten publiceras enbart i form av tabeller där enskilda personer inte kan identifieras.

\section{Sambearbetning av registerinformation}

\section{Steg 1. Identifiering av eventuella arbetspendlare}

Först identifieras den grupp av personer som haft ett anställningsförhållande med inkomst i arbetslandet (land A), men som inte är folkbokförda i land A den 31 december aktuellt kalenderår. Denna grupp har ofta ett personnummer som avviker från det vanliga personnumret. Födelsedatum går dock att utläsa utifrån detta speciella personnummer. För att senare kunna fullfölja datautbytet kopplas dessutom ett informationslöst löpnummer till varje person. Därefter sänds ett dataset med den 
aktuella populationen innehållande födelsedatum och namn till mottagande land B (bostadslandet).

\section{Steg 2. Utlämnande av bakgrunds- och arbetsmarknadsdata data från den eventuella bostadslandet (land B)}

I bostadslandet (land B) matchas födelsedatum och namn mot befolkningsregistret för att se vilka som är folkbokförda där. För de personer som identifierats i bostadslandet framställs ett dataset med demografiska uppgifter och uppgifter om person har även ett arbete i bostadslandet. Detta material lämnas till arbetslandet, vilket således omfattar de personer som återfunnits som folkbokförda i land B och som haft arbete i land A. Därmed vet man hur många personer som bor i land $\mathrm{B}$ och som haft ett anställningsförhållande i land A.

\section{Steg 3. Komplettering med data från arbetslandet (land A)}

När materialet återkommer till arbetslandet kompletteras det med data om personernas arbete i arbetslandet. Därmed är möjligt att avgöra i vilket land som personernas huvudsakliga arbete bedrivits. Utifrån dessa uppgifter fastställs vilka personer som skall klassificeras som arbetspendlare över riksgräns. När detta arbete är färdigt sänds det aktuella materialet till bostadslandet (land B).

\section{Steg 4. Ett komplett material sänds åter till bostadslandet (land B)}

I och med att bostadslandet erhållit det färdiga materialet från arbetslandet är det möjligt att redovisa statistik om den aktuella populationen.

I bilagan Variabelbeskrivning för arbetspendling över riksgräns redovisas variabelutbytet i detalj.

\section{Löntagare med inkomst i annat land}

Begreppet löntagare med inkomst i ett annat land omfattar dels de personer som klassats som arbetspendlare över riksgränsen, dels övriga löntagare med inkomst i landet.

Detta begrepp ger en helhetsbild av flödet av arbetsinkomster över en riksgräns. I redovisningen ingår förutom antalsredovisningar av antalet personer även tabeller över lönesummor m.m.

\section{Arbetpendlare över riksgräns, klassificering}

För att räknas som arbetspendlare över riksgräns ska den aktuella personen inneha ett jobb som täcker november månad i arbetslandet under det aktuella året. Dessutom krävs att personen uppnår en inkomstnivå motsvarande 4 timmars arbete för denna månad. Slutligen skall inkomsten överstiga inkomsten i hemlandet för samma kalenderår.

När steg 3 är genomfört finns underlag för att klassifiera arbetspendlare över riksgräns. Detta avgränsningsarbete görs i arbetslandet där man också framställer de tabeller som skall användas vid statistikredovisningen. 


\section{Sitter du fast i byråkratin?}

Då kan Hallå Norden hjälpa dig. Vi svarar på frågor i samband med flyttning, resor, pendling eller studier och lotsar dig vidare i systemen.

Du är välkommen att kontakta Hallå Norden när du har frågor om formaliteter i samband med gränsarbete, studiemedel, värdering av studier, sjukvård, sjukförsäkring, föräldrapenning, rätten att använda ditt modersmål vid myndighetskontakter, pensioner intjänade i annat nordiskt land, medborgarskap inom Norden, införsel och registrering av bil med mera.

Hallå Norden är Nordiska ministerrådets informationstjänst för privatpersoner som rör sig mellan de nordiska länderna och på ett eller annat sätt hamnar snett i byråkratin. Vid brister i regelverken rapporteras dessa vidare till myndigheterna i Norden.
YTTERLIGARE INFORMATION om Hallå Norden finner du på www.hallonorden.org

Du kan också kontakta oss på telefon eller via e-post:

SVERIGE

+ 46850611323

halla@norden.se

DANMARK

$+4570201093$

info@hallonorden.dk

F IN LAN D

+358201980088

hallo@pohjola-norden.fi

ISLAND

+3545111808

hallo@norden.is

NORGE

+4721021999

hallo@norden.no

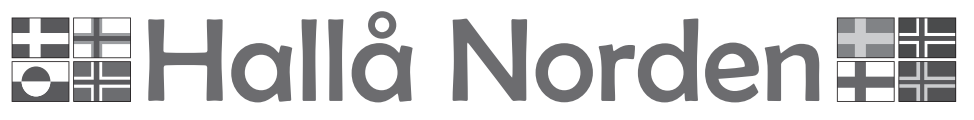


Nordisk Ministerråds og Nordisk Råds publikationer kan bestilles hos:

\section{BELGIEN \& LUXEMBOURG}

Jean de Lannoy

Avenue du Roi, 202, 1190 Brussels

$\mathrm{Tel}+32$ (0)2 $5385169 \mathrm{Fax}+32$ (0)25380841

jean.de.lannoy@euronet.be

\section{CANADA}

Renouf Publishing Company Ltd

5369 Canotek Road, Ottawa, Ontario K1J 9J3

Tel + 1 (613) $7452665 \mathrm{Fax}+1$ (613) 7457660

order.dept@renoufbooks.com

www.renoufbooks.com

\section{DANMARK}

Svensk-Norsk Bogimport A/S

Esplanaden 8 B, 1263 København $\mathrm{K}$

Tel +4533142666 Fax +4533143588

snb@bog.dk

www.snbog.dk

\section{ESTLAND}

Astro Raamatud AS

Pärnu mnt 142, 11317 Tallinn

Tel +372 6548485 Fax +372 6548475

book@astro.ee

\section{FINLAND}

Akademiska Bokhandeln

PB 128, Centralgatan 1, 00101 Helsingfors

Tel +358 912141

akatilaus@akateeminen.com

www.akateeminen.com

\section{FRANKRIG}

Librairie LAVOISIER

14, rue de Provigny, 94236 Cachan Cedex Tel +33 (1) $47406700 \mathrm{Fax}+33$ (1) 47406702 group@lavoisier.fr

www.lavoisier.fr

\section{F/ERøERNE}

H.N. Jacobsens Bókahandil

Postboks 55, 110 Tórshavn

Tel +29831 $1036 \mathrm{Fax}+298317873$

hnj-bokh@post.olivant.fo

\section{HOLLAND}

De Lindeboom Internationale Publicaties b.v. M.A. de Ruyterstraat 20 A, NL-7482 BZ Haaksbergen Tel +31 (0)53 $5740004 \mathrm{Fax}+31$ (0)535729296 books@delindeboom.com

www.delindeboom.com

\section{ISLAND}

Mál og Menning

Laugavegi 18, 101 Reykjavik

Tel +354 (9)5152500 Fax +354 (9)5152505

verslun@mm.is

\section{KINA}

CNPIEC

Europe Division 16 Gongti East Road

P.O. Box 88, Beijing

Tel +86105066 688-8 Fax +86105063101

\section{LETLAND}

Jana Rozes Gramàtnica

Kr. Barona iela 5, 1011 Riga

Tel +371 (0)2 284288 Fax +371 7370922

\section{LITAUEN}

Penki Kontinentai

A. Stulginskio 5, 2001 Vilnius

Tel +370 (5) 2664540 Fax +370 (5) 2664565

books@5ci.lt

www.books.lt

NORGE

Akademika A/S

Postboks 84 Blindern, 0314 Oslo

Tel +4722853030 Fax +4722853080

bloken@sio.uio.no

www.akademika.no

\section{RUMAENIEN}

Euromedia s.r.l.

Str Dionisie Lupu nr 65, 70184 Bucuresti

Tel + 4016140664 Fax + 4013129646

\section{STORBRITANNIEN}

The Stationery Office

P.O. Box 276, London SW8 5DT

Tel +44 8706005522 Fax +44 8706005533

customer.services@tso.co.uk

www.tso.co.uk/bookshop

\section{SVERIGE}

Fritzes

Kundservice, 10647 Stockholm

Tel +46 (0)8 6909190 Fax +46 (0)8 6909191

order.fritzes@nj.se

www.fritzes.se

\section{TYSKLAND}

UNO-Verlag GmbH

Am Hofgarten 10, 53113 Bonn

Tel +49 (0)228949020 Fax +49 (0)2289490222

info@uno-verlag.de

www.uno-verlag.de

\section{UNGARN}

Euro Info Service

PO Box 1039, 1245 Budapest

Tel +36 (1) 3292487 Fax +36 (1) 3492053

euroinfo@euroinfo.hu

\section{USA}

Bernan

4611-F Assembly Drive, Lanham MD 20706-4391

Tel +1 (301) 4597666 Fax +1 (301) 4590056

query@bernan.com

www.bernan.com

\section{ÅLAND}

Lisco bok- och pappershandel

Skarpansvägen 25, Box 8, 22101 Mariehamn

Tel +358 (0)18 $17177 \mathrm{Fax}+358$ (0)18 19771 info@lisco.fi 